\title{
Farkl1 Kültürler İçerisinde Eğitim Gören 12-17 Yaş Grubu Türk Çocuklarının Estetik Beğeni Düzeylerinin Karşılaştırılması ${ }^{1}$
}

DOI: $10.26466 /$ opus. 470120

\author{
$\underline{\text { Hatice Kübra Özalp }}^{*}$ - Melek Gökay ${ }^{* *}$ \\ ${ }^{*}$ Dr. Öğr. Üyesi, Necmettin Erbakan Üniversitesi Ahmet Keleşoğlu Eğitim Fak. Konya/ Türkiye \\ E-Posta: hkozalp@konya.edu.tr \\ ORCID: 0000-0001-6710-3117 \\ ** Prof. Dr., Necmettin Erbakan Üniversitesi Ahmet Keleşoğlu Eğitim Fak. Konya/ Türkiye \\ E-Posta: mgokay@konya.edu.tr \\ ORCID: 0000-0002-4788-6115
}

\section{Öz}

Bu araştırmada Batı ve Türk kültüründe yaşayan Türk öğrencilerin Türk kültürü ve Batı kültürü algıların ve buna bağh olarak değişeceği düşünülen estetik beğenilerini tanımlamak ve karşılaştırmak amaçlanmıştır. Nicel ve nitel araştırma yöntemlerinin birlikte kullanıldığı karma araştırma modeli ile desenlenen bu araştırma Almanya ve Türkiye'de yaşayan 12-17 yaş grubu toplam 310 Türk öğrencinin katılımıyla gerçekleştirilmiştir. Ankette yapıldığı dönem, biçim, form, renk ve konu bakımından benzerlik gösteren Batı ve Türk kültüründen birer eserin yer aldiğg 15 soru bulunmaktadır. Öğrenciler her soru için beğendikleri bir eseri tercih etmişler ve her soruda bu eseri neden tercih ettiklerini belirten ifadeler yazmışlardır. Anketten elde edilen nicel veriler SPSS programında (iki yönlü) Kay-Kare testi ile analiz edilmişsir. Kültürü yansıtan eserlerin farklı kültürlerde yaşayan insanlar üzerindeki etkilerini ortaya koymayı amaçlayarak elde edilen öğrenci cevapları ise içerik analizi ile analiz edilmiştir. Araştırmanın sonucunda öğrencilerin estetik tercihlerinde ait olduklar kültürün etkisi hissedildiği gibi içinde yaşadıkları diğer kültürlerin de etkisinin olduğu anlaşılmıştır. Öğrencilerin estetik beğenilerinde dil, din, vatan sevgisi, popüler kültür ve geleneksel kültür motifleri gibi kültürel faktörlerin etkisinin yoğunlukta olduğu görülmüştür.

Anahtar Kelimeler: Kültür, Estetik Tercih, Estetik Beğeni, Sanat Eğitimi.

\footnotetext{
${ }^{1}$ Bu araştırma, Necmettin Erbakan Üniversitesi Eğitim Bilimleri Enstitüsü, Güzel Sanatlar Eğitimi Anabilim Dalı, "12-17 Yaş Grubu Türk ve Alman Çocuklarının Estetik Beğeni Düzeylerinin Karşılaştırılması" adlı Doktora Tezinden üretilmiştir. Araştırmanın Almanya'da yaşayan Türk ve Alman çocuklar üzerinde yapılması süreci UNESCO-Kültür eğitimi öğrenci danışmanı Dr. Ernst Wagner ile birlikte yürütülmüştür. Araştırmaya Deutscher Akademischer Austauschdienst (DAAD) burs vererek destek olmuştur.
}

OPUS @ C Uluslararası Toplum Araştırmaları Dergisi-International Journal of Society Researches ISSN:2528-9527 E-ISSN : 2528-9535

http://opusjournal.net 


\title{
Comparison of Aesthetic Appreciation Levels of 12- 17 Years of Age Turkish Children Studying in Different Cultures
}

\begin{abstract}
In this study, it is aimed to define and compare the Turkish culture and Western culture perceptions of Turkish students living in Western and Turkish cultures and their aesthetic appreciation which is thought to change accordingly. The study, designed with a mixed research model that combines quantitative and qualitative research methods, was carried out with participation of a total of 310 Turkish students of 12-17 years of age living in Germany and in Turkey. In the survey, there are 15 questions including an artwork from each of the Western culture and the Turkish culture, which are similar in terms of the style, form, colour, subject and age of production. The students chose the work they appreciated for each question and wrote explanations why they preferred that work in every question. The quantitative data obtained from the questionnaire were analysed by (two way) Chi-Square test in the SPSS program. The students' responses, gathered with the aim of revealing the effects of the works reflecting the culture on people living in different cultures, were analysed by content analysis. As a result of the research, it is understood that besides feeling the effect of the culture they belonged to on the aesthetic preferences of the students, the other cultures they live in also have an effect on them. The effects of cultural factors such as language, religion, patriotism, popular culture and traditional culture motifs were found to be intense in students' aesthetic appreciation.
\end{abstract}

Keywords: Culture, Aesthetic Preference, Aesthetic Appreciation, Art Education

OPUS (c) Uluslararası Toplum Araştırmaları Dergisi-International Journal of Society Researches ISSN:2528-9527 E-ISSN : 2528-9535

http://opusjournal.net 


\section{Giriş}

İnsanın estetik gelişimi estetik varlığı algılamasıyla şekillenir. Toplumsal değerler ve insanın öz değeri kendi estetik görüş ve anlayışını oluşturmaktadır. Estetik biçim, özerklik ve gerçeklik karşılıklı ilişkilidir. Her biri toplumsal-tarihsel bir fenomendir ve her biri toplumsal tarihsel arenay1 aşar (Marcuse, 1997, s. 20). Estetik oluşumun geçmişten günümüze mayalanması estetik biçime değer kazandırmış; ona nasıl yaklaşılması gerektiğinin anlaşılmasını sağlamıştır. Düşündüklerimiz ya da inandıklarımız nesneleri görüşümüzü etkiler diyen Berger (2009, s. 13), sözcüklerden önce gelen ve sözcüklerle tam olarak anlatılamayan görmeyi, uyar1cılara karşı mekanik bir tepkide bulunup bulunmama sorunu olarak görmemektedir. O, bunu bir tercih olarak kabul etmektedir. Eisner (2002) ve Dewey'in (1934) görüşleri estetik gelişimde önemli bir yer tutmaktadır. Bu görüşlere göre, estetik günlük yaşamı anlatabilen basit yollardan biridir. Yani bakmak, farklılıklara ve benzerliklere tepki göstermek, hissetmek, doku ve formların farkında olmak, çevredeki objeleri sevmek ya da sevmemek estetik gelişimin ve estetik tepkinin bir parçasıdır (Aktaran: Eckhoff, 2006, s.23). Bu durumdan yola çıkarak öğrencinin bir bakıma onun eğitimiyle birlikte yaşadığı çevreyi, yetişme tarzını, kültürünü değerlendirmek onların estetik beğenileri ve tercihlerini anlamakta faydalı olacaktır. Çünkü her coğrafyanın kendine ait bir durumu ve bu durumun etkisi altına aldığ 1 toplum ve bunun içinde de bireylerin ortaya çıkan görüş ve fikirleri bulunmaktadır. Dünya üzerinde pek çok kültür ve eğitim sisteminin olduğunu kabul edersek bu çeşitliliği birbiri ile değerlendirmek kültür ve eğitim faktörünün estetik beğeni oluşumunda belirginliğini ortaya çıkaracaktır.

\section{Estetik}

Sanat eserinin sanatsal karakteri izleyiciye sunulduğunda sadece sanat eserinin görünen yüzü ifade edilebilir, açılanamaz. Analiz etmek sanat eserinin derinlerinde bulunan duyguları ve sanatsal değerinin anlaşılmasını sağlamaz, sadece eserin sergilenebilir durumunu ortaya çıarır. Bu durumda estetik, sergilenen objenin derinlerindeki gizemi çözmektir. Bu gizemi çözmeye çalışmak çağlar boyunca süre gelen bir düşünce sis- 
temidir. Holt (2001, s. 13), estetiğin, Rönesans boyunca klasik dönemden miras kalan güzelliğin antik felsefesinin bir sonucu olduğunu ifade etmektedir. Micheal Kelly (1998) ise, estetiği basit olarak sanata, kültüre ve doğaya karşı eleştirel yaklaşım olarak tanımlamaktadır (Akt: Smith, 2008, s.4).

Bu açıdan bakıldığında sanat ve estetik, çağdaş yaşamın deneyimlerine hem karşı koyan hem de bu deneyimleri kabul eden açık bir çevreyi önerir. Estetiğin, her tanımlamada sanatı anlama ile ilgili olduğu kabul edilmiştir. Sanatı anlamak ise sanat ürünü dediğimiz objelerin zihinde canlandırdığı etkiyi araştırmayı ya da algısal problemlere eğilmeyi gerektirir. Objelerin zihinsel algısı denildiğinde Marksist estetiğin temel savlarından biri olarak yansıma kuramı düşünülebilir. Bu kurama göre insan bilinci çevresel gerçekliğin bir imgesidir, nesnel dünyanın öznel bir tasarımıdır. Yansıma kuramı gerçeğin insan zihninde yansıtımına ilişkin tasarlanmasıdır. Örneğin Tunalı'ya göre (2011, s. 60) Marksist estetik için sanatın objesi olan gerçeklik, insanın dışında, ondan bağımsız olan bir gerçeklik olmayıp, insansal ve toplumsal bir gerçektir. Estetik gerçeklik insana bağlı gerçekliktir. Buradan anlaşılacağı üzere Marksist düşünce için güzellik madde ve paradır; hümanist bir yaklaşım için güzellik insan ve sevgidir. Güzellik anlayışı ve güzele bakış sahip olunan anlayışa göre değişim gösterebilir. Güzel, insanın hem içindeki duyguları dışsallaştırması hem de yaşadığı çevre ve toplumsal sürecin bir yansıması olarak anlamlandırılır. Bu durum estetik objeyi psikolojik obje olarak algilamaktır. Yani bir objeye karşı duyulan his süjeye bağlı bir değer ise bu durum, biçimlerde süjenin kendi idealini yakalama ve objeden haz duymasıdır. Güzellik, şeylerin kendilerinde olan bir özellik değildir, sadece düşüncelerimizin olduğu zihinde var olan bir olgudur. Her zihin farklı bir güzelliği algılar ve dahası gerçek güzelliği ya da gerçek bozulmayı aramak, gerçek tadı ya da acı durumu anlamaya engel bir gereksizlik olabilir. Bu düşünce, basit anlamda bir objenin güzelliğinin, ne görünüşüne ne de bir objenin objektif olarak veya birbirinden bağımsız olan algısal niteliğe bağlı olduğunu varsayabildiğimizi açıklamaktadır (Guyer, 2005, s. 38). Duyulara bağlı olan estetik anlayış, "insan sadece güzel olan şeyi mi algılar?" sorusuyla ilgilidir. Sadece güzeli değil "acı" hissetmek de sanatta estetiği uyandırabilir. "Aesthetic outrage" denilen bir objeden ya da bir olaydan etkilenmek veya rahatsızlık duymak da de- 
rinden etkilenmedir ve bu da estetik hazdır (Berleant, 2010, s. 28). Duyulan hazzın sonunda gerçekleşen tercihler ve estetik deneyim bize aşina gelen ve haz duyulan şeyler temeline dayanır diyen Blocker (1993, s.26), her deneyimle yaşanan tercihte kişinin kendine göre haklılık payı olduğunu ifade etmektedir. Bu nedenle aynı objede ya da olguda kötü- iyi, güzel-çirkin değerler vücut bulabilir. İçimizde barındırdığımız bütün sezgilerin doğru olduğunu düşünen Hume'un, doğrunun ve yanlışın kriterlerinin ne olduğu konusunda kastettiği şey doğru ya da yanlış sezgileme değildir. Güzellik, şeylerin içinde olan bir özellik değildir fakat onların zihinde tamamlanan bölümü ve her zihinde farklı bir güzellik olarak görünen şeydir. Bu doğrultuda güzelliğin algılanmasında Kieran (2011), Prinz (2011), Schenkman ve Jönsson (2000) güzelliğin kişinin bakış açısına göre değişmesi ile ilgili araştırmalar yapmıştır. Kişinin bakış açısının şekillenmesinde ise kültür önemli bir belirleyici olarak görülmektedir.

\section{Kültür}

Kültür, insanın kaderini belirleyen bir arada yaşam, duygu ve kuralların harmanlandığı, insan zihninde ve toplumun vitrininde zamana yayılan simgeler bütünüdür.

Tylor'un tanımına göre, "Bilgi, inanç, sanat, ahlak, hukuk, örf ve adetlerden ve insanin toplumun bir üyesi olarak elde ettiği bütün yeteneklerden oluşan karmaşık bir bütündür." (Turhan, 1972, s.39-40; Aktaran: Güneş, 2004, s.92). Burada kültürü anlayabilmek için toplumu iyi çözümlemek gerekir. Toplum denilen kader birliği yapmış gruplar, aynı coğrafi alanda yaşayıp bu şartlara uygun ortak bir yaşam metodu oluştururlar. Tarih, inanç, ahlak, örf-adet, giyinme, beslenme alışkanlıkları gibi geçmişi göz önünde bulundurarak geleceğe yön veren, insanları programlayan ortak sistematik bir çarkın içinde olgunlaşmaktadır toplum. Örneğin her toplum ve kültür yaş gruplaması, bedensel süslenme, ahiret inancı, yemek kuralları, hediyeleşmek, akrabalık, cezai yaptırımlar, ikamet kuralları gibi pek çok şeyleri tanır ve her kültür bunları kendine göre şekillendirir (Boersema, 2013, s.193). Kültürün toplumsal bir yaratı olduğu ve bireyi temel alarak oluşturulan sınıflandırmayı Erinç'in (2004, s.11-12) bireysel kültür, yöresel ya da ulusal kültür, evrensel kültür şeklinde yaptığ1 gö- 
rülmektedir. Bireysel kültür, kişisel eğitim yoluyla edinilen kazanımlardır. Bu anlamda sanat kültürden ayrı tutulamaz. Bireysel kültür sanatsal anlayışı da etkilemektedir. Eagleton (2011, s.14) kişisel kültürü, kişinin içsel denetimi olarak görmektedir. Yöresel ya da ulusal kültür, toplumu diğer toplumlara göre farklı kılan, özgün yapan özelliğidir. Evrensel kültür bütün toplumların ortak alanda özelliklerini sunduğu karma olan ve moda yöntemiyle etkinliğini hissettiren bir kültürdür. Burada her kültür için biraz bozulmuşluk hissedilir ve bu durum popüler kültürün işaretidir. Popüler sanatın verdiği geçici haz ve eğlencenin büyüsüne kapılan toplumun sonunda doyumsuz ve mutsuz bir hal almasını tüketim kültürü ve politik bir olgu olarak açıklayan Baudrillard (2013), Adorno (2011), Aslan (2010), Canclini (1999) ve Gans (2014)'ın çalışmaları bulunmaktadır. Bu çalışmalarda vurgulanan durum popüler kültürün tüketime dayalı bir haz ve beğeni anlayışı oluşturma politikasının varlığıdır. Tüketim ilkesinin erekselliğinde haz yoktur ancak zorunlu bir haz vardır. Tüketim kültürü aslında hazzı ve mutluluğu da tüketmektedir. Böylelikle toplumlarda benzer ve küresel bir beğeni anlayışının oluştuğu da görülmektedir.

Sanatın toplumsal değerlerin her biri ile ayrı ayrı ilişkisi bulunur. Toplumların dininde, ahlakında, biliminde, eğitiminde, ticaretinde, teknolojisinde, politikasında, eğlencesinde ve hukuk sisteminde bu görülür (Boersema, 2013, s.193). Sanat eserleri toplumun aynası gibidir diyen Erinç (2004, s.71), toplumun müziği, edebiyatı, gösteri ve plastik sanatlar1 ve bunların ürünü olarak görülen, güzellikleriyle övünülen her şeyi sanat olarak nitelendirmiştir. Bunlardan gelecek her yansıma kültürün bir anlatısı, her bozulma da kültürel bozulmadır. Kültürel motifler, ait olduğu coğrafyadaki zihinler tarafından her zaman ayırt edilir. Kültürel anlamlar ve onları taşıyan sembol sistemi şekillerin ilişkisel anlamlarını muhafaza etmelerini sağlar. Dil ve hilal, bayrak gibi kültürel anlama sahip şekillerin başında gelir. Sembollerin anlamı üzerinde toplum içinde bir anlaşma olduğu için bunlar ortak bir anlama sağlarlar (Mardin, 2014, s.51). Her insan bir çevrede büyümektedir. İnsan doğduğu yere bağlı değil de daha çok farklı yerlerde gezdiği ya da yaşadığı yerdeki kültür değişimini yaşamaktadır. Mesela, birkaç yıl başka bir yerde yaşayan insan doğduğu yerin kültüründen uzaklaşıp yaşadığ yerin kültürüne alışmış olabilir. Bu durum kültürlerin birbirine karışmasına neden 
olmaktadır. Yani insanlar tekrar kendi ülkelerine döndüklerinde sonradan yaşadığı kültürün etkisi unutulmaz, bunlar günlük yaşamda etkisini sürdürmeye devam eder. Göçmenlerin çocuklarında görülen şey de ailelerinden aldıkları kendi kültürlerini yaşadıkları yerin deneyimlerine karıştırmalarıdır (Bösel, 2012, s.9).

Kültür yanında eğitimin estetik beğeni ve yargı üzerine etkisi de yadsınamaz. Çünkü sanat, yalnız belli bir kültüre dayanmakla kalmaz, aynı zamanda özellikle eğitim isteyen bir fenomendir (Tunalı, 2011, s.36). Schiller'in (1999) içtepi dediği insanın içinde ve dışındaki kuvvetlerin uyumlu birlikteliğini sağlamak, duygu yetisini geliştirmektir. Estetik eğitiminde temel amaçlardan biri, bilgilendirmek ve aydınlatmak; yaşam ve kültür ile ayrılmaz bağı olan sanatın rolünü tanımlamak ve öğrencilerin kendi yargılarını formüle etmelerini sağlayacak entelektüel araçlar sunmaktır (Loudermilk, 2002, s.5). Gökay (2004, s.40), görsel tasarımların öğrenciler tarafından değerlendirilebilmesi için kültürün olabildiğince okul ortamı içine çekilip öğrencileri bilinçlendirmek gerektiğini ifade etmektedir. Sanat konularının ülkelere göre değişim göstermesi çocukların tercihlerindeki değişimin temsili olabilmektedir. Bunun gibi tespitlerin yapılması anlamında "sanat eğitiminde bilgi ağı" yöntemi, sanat eğitiminin geliştirilmesi için gerekli olan yeterliliği sağlamak gibi amaçlara erişimi sağlamaktadır (Wagner, 2013, s.109). Bir çocuk bir resme bakıp "Bu resim güzel." dediğinde, kendine göre eleştirel bir karar cümlesi söylemiştir. Öğrencinin fikrini ve beğenisini açığa vuran bu cümlenin anlamının ne olduğunun araştırılması gereklidir. Güzellik, çirkinlik ve bunlara bağlı olarak verilen karar cümleleri tamamen göreceli terimler midir yoksa bakış açısına mı bağlıdır? Bu deyimler kültür eğitimine nasıl bağımlıdır? Belirli bir zaman ve yerden başka bir zaman ve yere göre değişir mi? gibi soruların cevabının düşünülmesi, insanın özellikle karar verdiği sözcüklerin anlamını açıklamaya yardımcı olacaktır (Gökay, 1998, s. 39).

Bu kapsamda yapılan araştırmanın amacı farklı kültürlerde yaşayan ve eğitim alan öğrencilerin estetik beğeni düzeylerinde görülen farklıllklar ve bu farklılıkları oluşturan etmenleri ortaya çıkarmak olarak belirlenmiştir. Bu doğrultuda aşağıdaki diğer alt araştırma sorularına cevap aranmıştır; 
1. Farklı kültürlerde yaşayan 12-17 yaş grubundaki Türk öğrencilerin estetik tercihlerinde kültürün etkisi var mıdır?

2. Estetik beğeniyi etkileyen faktörler nelerdir?

\section{Yöntem}

\section{Araştırma Yöntemi}

Karma araştırma modeli ile desenlenen bu çalışmada nicel ve nitel araştırma yöntemleri birlikte kullanılmıştır. Nicel araştırma, değişkenlerin duruma etkililik oranını sayısal verilere dayandırıp anlamlı farklar elde etme sürecidir. Değişkenler arasında ilişkileri aramak için en az iki değişkenden oluşan durumlar arasında karşılaştırma yapılmaktadır. Kültürler arası etkileşim çalışmalarında kullanılan karşılaştırmalı çalışmalar, farklı toplum içerisindeki bireylerin bir olaya karşı benzerlik ve farklılıklarını açıklamak üzere psikologların, antropologların, fen bilimci ve sosyologların kullandığı bir yöntemdir (Çepni, 2007, s. 48). Nitel araştırma desenlerinden olan kültür analizine yönelik çalışmalarda amaç belirli bir grubun kültürünü tanımlama ve yorumlamadır. Bu tanımlama genellikle o kültüre özgü kavramlar, süreçler ve algılar çerçevesinde yapılır. Bu nedenle araştırmaya dâhil olan katılımcıların kullandıkları yazılı ve sözlü dil, davranış kalıpları, algıları ve paylaştıkları deneyimler bir araştırmacının odaklanabileceği alanlar olarak ortaya çıar (Hancock, 2004; Akt: Yıldırım ve Şimşek, 2005, s. 70). Çalışmada, öğrencilerin tercihleriyle ilgili sosyal olguları anlamaya yönelik sorulan sorulardan elde edilen veriler değerlendirilmiştir. Nitel araştırma ile elde edilen veriler, nicel analizi destekleyecek şekilde içerik analizi yapılarak maddeler oluşturulmuştur. İçerik analizinde öğrencilerin yazıları, dil kullanımını sanatsal birikimleri ve deneyimleriyle birlikte ortaya koydukları tercih ifadeleri kullanılmıştır.

\section{Çalışma Grubu}

Araştırma kültürler arası karşılaştırmayı içermektedir. Bu amaçla Türkiye ve Almanya için iki çalışma grubu belirlenmiştir. Türkiye'deki çalış- 
ma grubu Konya il merkezindeki 12-17 yaş arasında bir ortaokul ve iki Anadolu Lisesinde öğrenim gören öğrenciler arasından çalışmaya gönüllü olarak katılan 150 öğrenciden oluşmaktadır. Bu grup, 50 erkek ve 100 kız öğrenciden oluşmuştur. Almanya'da Türk öğrencilere ilişkin çalışma grubunda ise, çok kültürlü üç Gymnasium okulunda öğrenim gören Türk öğrenciler arasından araştırmaya gönüllü olarak katılan 160 öğrenci yer almaktadır. Bu gruptaki öğrenciler 103 kız, 57 erkek öğrenciden oluşmaktadır. Araştırmaya katılan toplam öğrenci sayısı 310'dur.

\section{Tablo 1. Araştırmaya Katılan Öğrenci Gruplarının Yaşa Göre Dă̆ılımları}

\begin{tabular}{ccc}
\hline Yaş & $\begin{array}{c}\text { Almanya'daki } \\
\text { Türk Öğrenci Sayısı }\end{array}$ & $\begin{array}{c}\text { Türkiye'deki } \\
\text { Türk Öğrenci Sayısı }\end{array}$ \\
\hline 17 Yaş & 38 & 28 \\
16 Yaş & 23 & 24 \\
15 Yaş & 21 & 31 \\
14 Yaş & 26 & 24 \\
13 Yaş & 17 & 21 \\
12 Yaş & 35 & 22 \\
\hline Toplam & 160 & 150 \\
\hline
\end{tabular}

\section{Veri Toplama Süreci ve Analizi}

$\mathrm{Bu}$ araştırmanın anketi iki doğru cevaplı, tek tercihli ve gerekçe sunma üzerine hazırlanmıştır ve üç bölümden oluşmaktadır. İlk iki bölüm öğrencilerin sınıf, yaş ve okul gibi bilgilerini almaya dayalıdır. Anketin üçüncü bölümü 15 sorudan oluşmaktadır. Her soruda bir Türk kültürünü yansıtan bir de Batı kültürünü yansıtan iki eser sunulmaktadır. Öğrenciler bu eserlerden kendilerine yakın hissettikleri, beğendikleri eserden bir tanesini seçerek işaretlemişlerdir. Bu bölüm araştırmanın nicel boyutunu oluşturmaktadır. Öğrencilere her sorunun altında A ya da B resminden birini tercih etme nedenini üç madde ile açıklanması istenilen bir alan daha sunulmuştur. Burada öğrencilerin bilinçaltında olan şeyleri açığa çıkarmak ve beğenilerinin temeline inmeye çalışmak amaçlanmıştır. Bu bölüm ise araştırmanın nitel boyutunu oluşturmaktadır. Ankette kişisel bilgiler ve sosyal birikimler ile ilgili olan bölümler ilk 15 dakikada tamamlanmıştır. Son bölümde ise, öğrencilere her soruyu incelemeleri, tercihlerini işaretlemeleri ve beğeni sebeplerini yazmaları için ikişer da- 
kika süre verilmiş; anketin üçüncü bölümü 30 dakikada tamamlanmıştır. Son bölümdeki sorular slayt olarak hazırlanmış, projeksiyon makinesiyle tüm sınıfın görebileceği şekilde yansıtılmıştır.

Öğrencilerin estetik beğenileri arasındaki farkın belirlenmesi amacıyla hazırlanan anketin bu amacı gerçekleştirmeye uygun olup olmadığ1nın değerlendirilmesi amaciyla uzman görüşüne başvurulmuştur. $\mathrm{Bu}$ amaçla uzman değerlendirme formu hazırlanmıştır. $\mathrm{Bu}$ form, anketin temelini oluşturan farklı kültürden iki eserin (A ve B) kültürel yansıtım derecelerini öğrenmeye yöneliktir. Uzman görüşü almak üzere plastik sanatlar alanında uzman dört kişiden, ankette kullanılan eserler hakkında konu, biçim, form, renk, motif, doku gibi durumları göz önünde bulundurarak A ve B resimlerini ait oldukları kültürü ne kadar yansıttıkları konusunda derecelendirme yaparak değerlendirme yapmaları istenmiştir. Formda değerlendirilmesi istenen resimler 1'den 5'e kadar siralama ölçütü üzerinden değerlendirilmiştir. Uzmanlara "(1) Çok az", "(2) Az", "(3) Orta", "(4) İyi", “(5) Çok iyi” şeklinde beş seçenek sunulmuştur. Uzmanlar bu değerlendirmeyi her soruda yer alan A ve B resmi için yapmıştır. Uzman görüşleri doğrultusunda uygulanan anket sorularının araştırmanın amacı olan estetik beğeni arasındaki kültürel farkı belirlemeye uygun olduğu görüşü ortaya çıkmıştır.

Araştırma anketinin üçüncü bölümünde bulunan eserleri tercih bölümünden elde edilen nicel veriler SPSS programında (iki yönlü) KayKare testi ile çözümlenmiştir. Çok kategorili iki değişkenin oluşturduğu hücrelerdeki, gözlenen frekans ile beklenen frekansı karşılaştırarak, değişkenler arası ilişkiyi sorgulayan (parametrik olmayan) test, iki değişken için Kay-Kare olarak adlandırılır (Can, 2014, s.323). Araştırmanın örneklemini oluşturan Türkiye ve Almanya'da bulunan Türk öğrencilerin Batı sanatı ve Türk sanatına ait eserleri tercih oranlarına bu şekilde ulaşılmış ve veriler tablo haline getirilmiştir. Araştırmanın ikinci analiz kısmını oluşturan nitel veri analizi ise, tercih sorularının altında bulunan öğrencilerin tercih gerekçelerini kendi cümleleriyle belirttikleri bölümden elde edilmektedir. Nitel veri analizi, betimsel analiz ya da içerik analizi yaklaşımı ile yapılır. Temel amaç araştırmaya konu olan kültürün tanımlanması ve bu süreçte de bu kültürü oluşturan bireylerin ya da grupların algılarının, deneyimlerinin ve tutumlarının kendi bakış açıla- 
rından aktarılmasıdır (Yıldırım ve Şimşek, 2005, s. 71). İçerik analizi ile toplanan verileri açıklayabilecek kavramlara ve ilişkilere ulaşılmıştır.

\section{Bulgular ve Yorum}

Bu bölüm Almanya'da yaşayan Türk öğrencilerle Türkiye'de yaşayan Türk öğrencilerin farklı kültürlere ait iki esere ilişkin görüşlerinin değerlendirilmesi sonucu elde edilen bulgu ve yorumları içermektedir.

Birinci Soruya Ait Bulgular ve Yorumlar
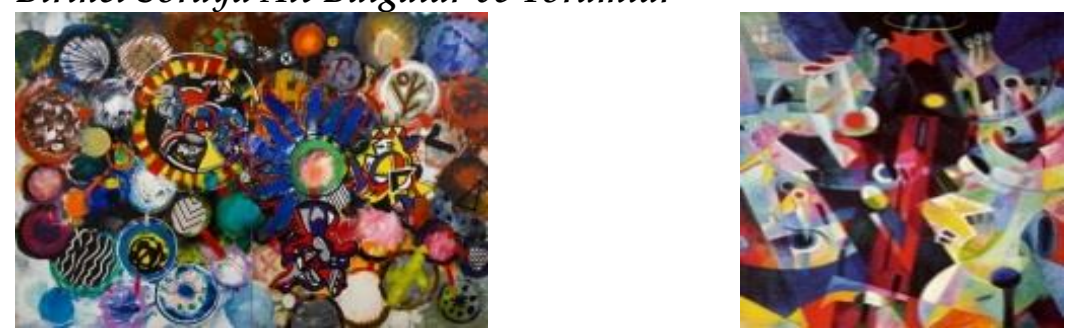

Tablo 2. Almanya'da ve Türkiye'de Yaşayan Türk Öğrencilerin Soru 1'de Batı ve Türk Sanat Eseri Tercih Dağılımları

\begin{tabular}{|c|c|c|c|c|c|c|c|}
\hline & & & \multicolumn{2}{|c|}{ S1 } & \multirow[b]{2}{*}{ Toplam } & \multirow[b]{2}{*}{$\mathbf{X}^{2}$} & \multirow[b]{2}{*}{$\mathbf{P}$} \\
\hline & & & Türk Sanatı & Batı Sanatı & & & \\
\hline \multirow[t]{4}{*}{ Grup } & & $\mathrm{f}$ & 82 & 77 & 159 & \multirow{6}{*}{.019} & \\
\hline & AT & $\%$ & 51,3 & 52 & 51,6 & & \\
\hline & & $\mathrm{f}$ & 78 & 71 & 149 & & .892 \\
\hline & $\mathrm{TT}$ & $\%$ & 48,8 & 48 & 48,4 & & $\mathrm{P}>.05$ \\
\hline \multirow[t]{2}{*}{ Toplam } & & $\mathrm{f}$ & 160 & 148 & 308 & & \\
\hline & & $\%$ & 100 & 100 & 100 & & \\
\hline
\end{tabular}

Tablo 2 incelendiğinde Almanya'da yaşayan Türk öğrencilerle Türkiye'de yaşayan Türk öğrencilerin estetik beğenilerinde oluşan değişimde farklı bir kültürel ortamda yaşamanın etkisi olup olmadığını belirlemek amaciyla sunulan resimleri tercih etmeleri arasındaki fark istatistiksel olarak anlamlı bulunmamıştır. $\left(X^{2}=.019, P>.05\right)$ 


\section{Almanya'da ve Türkiye'de Yaşayan Türklerin Soru 1 Tercihlerini Etki- leyen Temel Sebepler}

Almanya'da ve Türkiye'de yaşayan Türk öğrencilerin renk kullanımı, form yapısı ve geçmiş deneyim hatırlatma temalarına göre beğeni nedenlerinin oranları belirtilmiştir.

Tablo 3. Almanya'da ve Türkiye'de Yaşayan Türk Öğrencilerin Soru 1'de Batı ve Türk Sanat Eseri Tercih Dă̆ılımları

S1

\begin{tabular}{|c|c|c|c|c|c|c|c|}
\hline \multirow{3}{*}{ Grup } & \multicolumn{3}{|c|}{$\begin{array}{c}\text { Renk } \\
\text { Kullanımı }\end{array}$} & \multicolumn{2}{|c|}{ Form Yapisı } & \multicolumn{2}{|c|}{$\begin{array}{l}\text { Geçmiş Deneyim Hatır- } \\
\text { latma }\end{array}$} \\
\hline & & $\mathrm{f}$ & $\%$ & $\mathrm{f}$ & $\%$ & $\mathrm{f}$ & $\%$ \\
\hline & $\mathrm{AT}$ & 116 & 72,5 & 127 & 79,4 & 39 & 24,4 \\
\hline & $\mathrm{TT}$ & 119 & 79,3 & 117 & 78 & 43 & 28,7 \\
\hline
\end{tabular}

Bu soru için tercih edilen eseri beğenme nedeni olarak "Renk Kullanımı" teması için gösterilecek öğrenci ifadeleri şunlardır: "Daha sade ve huzur verici bir resim, uyumlu renkler var. Bana yılbaşını çağrıştıran bir resim." (TT138-A). "Resimdeki yuvarlaklar misketlere benziyor, her çemberin değişik motifi ve rengi var." (AT29-B). Bu soru için tercih edilen eseri beğenme nedeni olarak "Form Yapısı" temasında gösterilen yansitma yaziları şunlardır: "Farklı ırkları sembolize eden birçok iğne gibi görünüyor. Barışı ifade ediyor." (AT79-A). Bu soru için tercih edilen eseri beğenme nedeni olarak "Geçmiş Deneyim Hatırlatma" temasının gösterilebileceği yansıtma yazıları ise şunlardır: "Berlin Duvarı gibi görünüyor." (AT120-A). "Çünkü toplar var ve ben topu çok severim. Orada çok mavi var. Bana Seydişehir'den gelen hediyeyi hatırlatıyor. İçinde küçük resimler var." (TT146-B). Algıda, özellikle farklı şekillerde anlamlandırılabilecek işaretlerin algılanmasında eğilimlerin çok büyük rol oynadığı görülmektedir. 


\section{Íkinci Soruya Ait Bulgular ve Yorumlar}
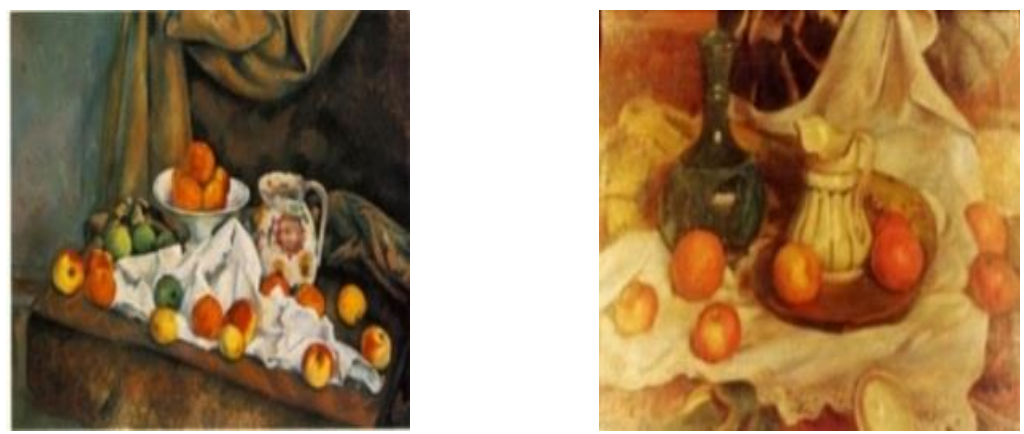

Tablo 4. Almanya'da ve Türkiye'de Yaşayan Türk Öğrencilerin Soru 2'de Batı ve Türk Sanat Eseri Tercih Dă̆ılımları

\begin{tabular}{|c|c|c|c|c|c|c|c|}
\hline & & & \multicolumn{2}{|c|}{$\mathrm{S} 2$} & \multirow[b]{2}{*}{ Toplam } & \multirow[b]{2}{*}{$\mathbf{X}^{2}$} & \multirow[b]{2}{*}{$\mathbf{P}$} \\
\hline & & & Batı Sanatı & Türk Sanatı & & & \\
\hline \multirow[t]{4}{*}{ Grup } & & $\mathrm{f}$ & 90 & 69 & 159 & \multirow{6}{*}{1.078} & \multirow{6}{*}{$\begin{array}{c}.299 \\
P>.05\end{array}$} \\
\hline & AT & $\%$ & 49,2 & 55,2 & 51,6 & & \\
\hline & & $\mathrm{f}$ & 93 & 56 & 149 & & \\
\hline & $\mathrm{TT}$ & $\%$ & 50,8 & 44,8 & 48,4 & & \\
\hline \multirow[t]{2}{*}{ Toplam } & & $\mathrm{f}$ & 183 & 125 & 308 & & \\
\hline & & $\%$ & 100 & 100 & 100 & & \\
\hline
\end{tabular}

Tablo 4 incelendiğinde Almanya'da yaşayan Türk öğrencilerle Türkiye'de yaşayan Türk öğrencilerin estetik beğenilerinde oluşan değişimde farklı bir kültürel ortamda yaşamanın etkisi olup olmadığını belirlemek amaciyla sunulan resimleri tercih etmeleri arasındaki fark istatistiksel olarak anlamlı bulunmamıştır. $\left(X^{2}=1.078, P>.05\right)$

\section{Almanya'da ve Türkiye'de Yaşayan Türklerin Soru 2 Tercihlerini Etki- leyen Temel Sebepler}

Almanya'da ve Türkiye'de yaşayan Türk öğrencilerin renkler, nostalji hissi; realizm; kültürel obje, kompozisyon ve geçmiş deneyim psikolojik etki temalarına göre beğeni nedenlerinin oranları belirtilmiştir. 
Tablo 1. Almanya'da ve Türkiye'de Yaşayan Türk Öğrencilerin Soru 2'de Tercih Nedenlerine Göre Dă̆ılımları

S2

\begin{tabular}{|c|c|c|c|c|c|c|c|c|c|c|}
\hline \multirow{4}{*}{ Grup } & & \multicolumn{2}{|c|}{$\begin{array}{c}\text { Renkler, } \\
\text { Nostalji Hissi }\end{array}$} & \multicolumn{2}{|c|}{ Realizm } & \multicolumn{3}{|c|}{$\begin{array}{l}\text { Kültürel Obje, } \\
\text { Kompozisyon }\end{array}$} & \multicolumn{2}{|c|}{$\begin{array}{c}\text { Geçmiş Deneyim } \\
\text { Psikolojik Etki }\end{array}$} \\
\hline & & $\mathrm{f}$ & $\%$ & $\mathrm{f}$ & $\%$ & & $\mathrm{f}$ & $\%$ & $\mathrm{f}$ & $\%$ \\
\hline & AT & 12 & 75,6 & 52 & 32,5 & & 58 & 36,3 & 54 & 33,8 \\
\hline & TT & 100 & 66,7 & 46 & 30,7 & 90 & & & 44 & 29,3 \\
\hline
\end{tabular}

Soru 2 için renkler, nostalji hissi temasında öğrencilerin şu cevaplarını incelemek mümkündür: "Sarı renkten dolayı eski zaman gibi görünüyor. Çok eşya olmadan nostalji hissi, özgürlü̈̆̈̈ hissediyorum, çünkü bu resim boş bir odayı tasvir ediyor." (AT116-B). "Daha sade ve güzel, renk tonu bakımından sanki eskiden kalma gibi." (TT61-B). Realizm teması ile ilgili Almanya'da ve Türkiye'de yaşayan Türk öğrencilerin verdikleri cevaplar şu şekilde sıralanabilir: "Oryantalist görünüyor." (AT5-B). Almanya' da yaşayan Türk öğrencilerin gerçeklikte aradıkları unsurun geleneksel bir görüntü ve huzur dolu bir ortamı yansıtma durumu olmasıdır. "Çok sade ve sürahiyi sevdim. Kavanoz ve etrafindakiler süper." (TT122-B). Kültürel obje, kompozisyon teması resim üzerindeki objeleri ve belirli bir kompozisyon içerisinde sunulmasını her öğrencinin kendi yaşadığı çevre veya kültürüne göre algılanması ve yorumlanmasının incelenmesidir. Buna bağlı olarak alınan yanıtları şöyle sıralamak mümkündür: "Bana memleketimi hatırlatıyor." (AT1-B). "Resim daha yakın planda, Osmanlı'yı hatırlattı̆̆ı için ve meyveler belirgin olduğu için bu resmi seçtim." (TT118-B). "Geçmiş deneyim hatırlatma, psikolojik etki" temasında öğrencilerin bu resimler karşısında geçmişte yaşadıkları olay ya da olgulardan etkilenme ve bundan dolayı duygusal çözümlemeye gitmeleri sonucunda verdikleri cevapların değerlendirilmesi yapılmaktadır. Bu tema ile ilgili öğrenci görüşleri şunlardır: "Bana Ramazan ayını hatırlatıyor, fakirler için para harcama, sadaka verme düşüncesini aklma getiriyor." (AT117-A). "Beni çocukluğuma götürdü." (TT16-B). Bu cevaplardan da öğrencilerin çocukluklarına dair yaptıkları ve yaşadıkları olayların etkisi görülmektedir. Bu soruda resimler için daha sıcak, samimi ve rahatlatıcı etkileri hissetmek beğenide etkili olmuştur. 


\section{Üçüncü Soruya Ait Bulgular ve Yorumlar}
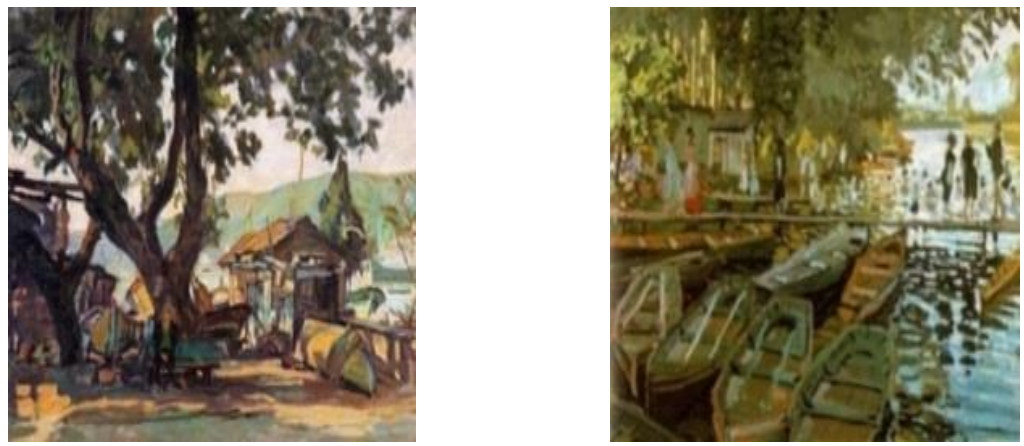

Tablo 6. Almanya'da ve Türkiye'de Yaşayan Türk Öğrencilerin Soru 3'te Batı ve Türk Sanat Eseri Tercih Dă̆ılımları

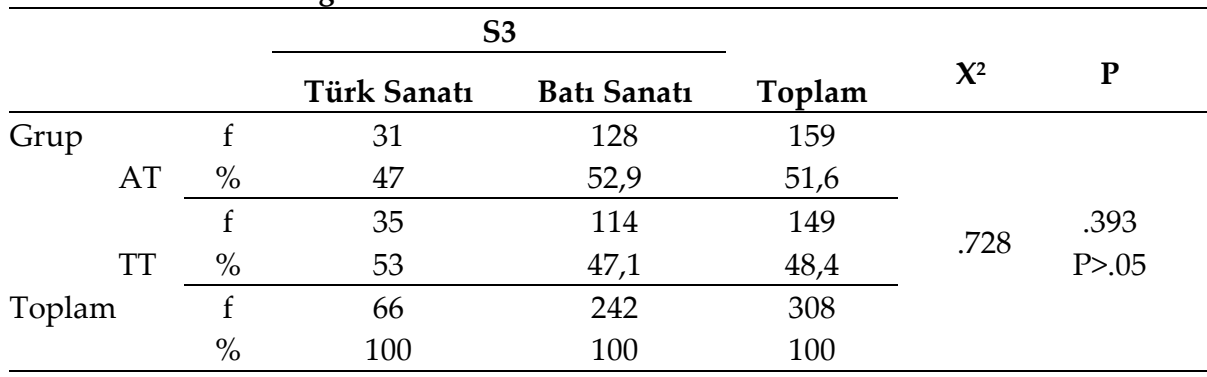

Tablo 6 incelendiğinde Almanya'da yaşayan Türk öğrencilerle Türkiye'de yaşayan Türk öğrencilerin estetik beğenilerinde oluşan değişimde farklı bir kültürel ortamda yaşamanın etkisi olup olmadığını belirlemek amaciyla sunulan resimleri tercih etmeleri arasindaki fark istatistiksel olarak anlamlı bulunmamıştır. $\left(X^{2}=.728, P>.05\right)$

\section{Almanya'da ve Türkiye'de Yaşayan Türklerin Soru 3 Tercihlerini Etki- leyen Temel Sebepler}

Soruyu cevaplayan Almanya ve Türkiye'deki Türk öğrencilerin tümünün yazdıkları nedenlerden yola çıkarak Soru 3 için dört alanda tema 
oluşturulmuştur. Bunlar, doğaya ait objeler, empresyonizm; renkler ve psikolojik etki; geçmiş deneyim ve realizm temalarıdır.

Tablo 7. Almanya ve Türkiye'de Yaşayan Türk Öğrencilerin Soru 3'te Tercih Nedenlerine Göre Dă̆ılımları

\begin{tabular}{|c|c|c|c|c|c|c|c|c|c|}
\hline \multicolumn{10}{|c|}{ S3 } \\
\hline & & \multicolumn{2}{|c|}{$\begin{array}{l}\text { Doğaya Ait Obje- } \\
\text { ler,Empresyonizm }\end{array}$} & \multicolumn{2}{|c|}{$\begin{array}{c}\text { Renkler, } \\
\text { Psikolojik Etki }\end{array}$} & \multicolumn{2}{|c|}{$\begin{array}{l}\text { Geçmiş } \\
\text { Deneyim }\end{array}$} & \multicolumn{2}{|c|}{ Realizm } \\
\hline & & $\mathrm{f}$ & $\%$ & $\mathrm{f}$ & $\%$ & $\mathrm{f}$ & $\%$ & $\mathrm{f}$ & $\%$ \\
\hline \multirow{2}{*}{ Grup } & AT & 116 & 72,5 & 81 & 50,6 & 54 & 33,8 & 49 & 30,6 \\
\hline & TT & 140 & 93,3 & 62 & 41,3 & 38 & 25,3 & 59 & 39,3 \\
\hline
\end{tabular}

Doğaya ait objeler ve empresyonizm teması için Almanya'da ve Türkiye'de yaşayan Türk öğrencilerin cevapları incelendiğinde şu sonuçlara varılmaktadır: "Çünkü çok hoş bir resim çok canlı. Köye benziyor, ağaçları çok güzel, baharı anlatıyor." (TT116-A). "Bu resimde beni en çok rahatlatan suyun üzerinde duran sakin kayalar, insanların varlığı ayrı bir neşe katıyor. Resimde yer alan göl, deniz ve aşağıya sarkan ağaçlar çok sıcak bir ortam yaratıyor." (AT38-B). Renkler, psikolojik etki temasında öğrencinin resmi beğenme ve tercih etme durumunu belirleyen renk ve duygusal anlamda etkilenme içeriği incelenmektedir. Bu alanda cevaplar incelendiğinde şu sonuçlara varılmaktadır: "Uzaktan bakınca evler çok denk görünüyor. Bu resme uygun müzik, Türk Sanat Müziği olur. Orada olsaydım uzaktan bakarken fotoğraf çekerdim." (TT121-A). "Rahatlamanın, sessizliğin ve barışın gösterilmesi." (AT72-B). Geçmiş deneyim teması içeriğinde öğrencilerin Almanya'da yaşayan Türklerin Türkiye'de yaşayan Türklere göre yaşanan olay ve olgularda değişimin olması yönündeki cevaplar incelenmektedir. Alınan cevaplar şu şekildedir: "Sevdiğim bir yeri hatırlatıyor: Türkiye." (AT127-B). Almanya'da yaşayan Türk öğrencilerin Türkiye'den izler taşıyan kimi zaman orada gittikleri bir yer kimi zaman aile büyüklerinin yaşadığ1 mekânlar, köyler beğenmelerinde etkin olmaktadır. "B resmi bana İstanbul'u hatırlattı. Sandalların ve gölün verdiği ışık iç açıcı, insanın içini açıyor." (TT138-B). Realizm temasında öğrencilerin beğenilerinde gerçeklik durumunun etkililiğini yorumlayan cevaplar şu şeklidedir: "Benim büyük kuzenim de böyle bir resim yapmıştl. Su gerçek görünüyor." 
(AT82-B). Çevredeki objelerin ve manzaranın canlılığ1 ve gerçekliğinin olması öğrencileri etkilemiştir.

\section{Dördüncü Soruya Ait Bulgular ve Yorumlar}
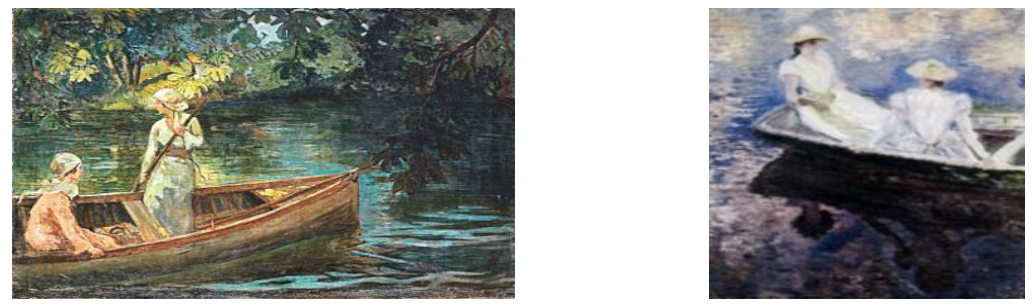

Tablo 8. Almanya'da ve Türkiye'de Yaşayan Türk Öğrencilerin Soru 4'te Batı ve Türk Sanat Eseri Tercih Dă̆ılımları

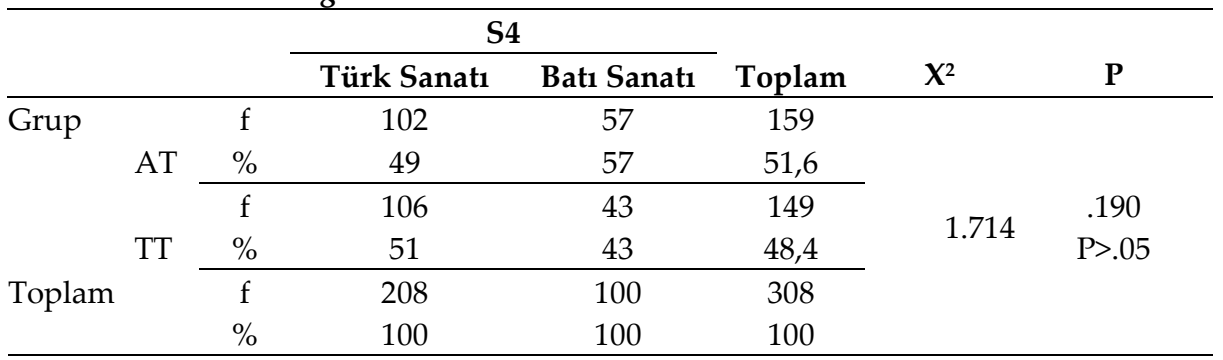

Tablo 8 incelendiğinde Almanya'da yaşayan Türk öğrencilerle Türkiye'de yaşayan Türk öğrencilerin estetik beğenilerinde oluşan değişimde farklı bir kültürel ortamda yaşamanın etkisi olup olmadığını belirlemek amaciyla sunulan resimleri tercih etmeleri arasindaki fark istatistiksel olarak anlamlı bulunmamıştır. $\left(X^{2}=1.714, P>.05\right)$

\section{Almanya'da ve Türkiye'de Yaşayan Türklerin Soru 4 Tercihlerini Etki- leyen Temel Sebepler}

Soruyu cevaplayan Almanya'da ve Türkiye'de Yaşayan Türk öğrencilerin yazdıkları bu nedenlerden yola çıkarak Soru 4 için beş alanda tema oluşturulmuştur. Bunlar, renkler; mekân içerisinde doğaya ait görünüm; 
kültürel obje, duygu ifade etme; geçmiş deneyim ve realizm, natüralizm temalarıdır.

Tablo 9. Almanya ve Türkiye'de Yaşayan Türk Öğrencilerin Soru 4'te Tercih Nedenlerine Göre Dağılımları

\begin{tabular}{|c|c|c|c|c|c|c|c|c|c|c|c|}
\hline \multicolumn{12}{|c|}{ S4 } \\
\hline & & \multicolumn{2}{|c|}{ Renkler } & \multicolumn{2}{|c|}{$\begin{array}{c}\text { Mekân } \\
\text { İçerisinde } \\
\text { Doğaya Ait } \\
\text { Görünüm }\end{array}$} & \multicolumn{2}{|c|}{$\begin{array}{l}\text { Külttürel Obje, } \\
\text { Duygu İfade } \\
\text { Etme }\end{array}$} & \multicolumn{2}{|c|}{$\begin{array}{c}\text { Geçmiş } \\
\text { Deneyim }\end{array}$} & \multicolumn{2}{|c|}{$\begin{array}{c}\text { Realizm } \\
\text { Naturalizm }\end{array}$} \\
\hline & & $\mathrm{f}$ & $\%$ & $\mathrm{f}$ & $\%$ & $f$ & $\%$ & $\mathrm{f}$ & $\%$ & $\mathrm{f}$ & $\%$ \\
\hline & AT & 110 & 68,8 & 104 & 65 & 56 & 35 & 30 & 18,8 & 58 & 36,3 \\
\hline Grup & TT & 82 & 54,7 & 10 & 68,7 & 61 & 40,7 & 14 & 9,3 & 77 & 51,3 \\
\hline
\end{tabular}

Renkler temasında öğrencinin resmi beğenme ve tercih etme durumunu belirleyen renkler ve oluşturduğu etki üzerine yantlar incelenmektedir. Bu alanda cevaplar incelendiğinde şu sonuçlara varılmaktadır: "Denizin rengi çok güzel, çok parlak bir resim." (TT116-A). "Kadınların elbisesi beyaz ve bu özgürlüğ̈̈ temsil ediyor." (AT145-B). Mekân içerisinde doğaya ait görünüm temasında Almanya ve Türkiye'de yaşayan öğrencilerin resimleri doğa içerisindeki objelerin, figürlerin algılanması ve yorumlamaları değerlendirilmektedir. "Ağaçlar çok dikkatimi çekti. Çünkü oranın havası başkadır. Orada olsam dünyayı turlamak isterdim. Balık tutmak istedim." (TT146-A). "Özgürlük anlamına gelen çok doğa manzarası var. Ayrıca dar bir nehrin içindeler ve bu tehlike oluşturuyor. Koyu renkler tehlike ve macera." (AT116-A). Kültürel obje, duygu ifade etme temasında öğrencilerin verdikleri yanıtlarda resimdeki kültürel ayrıntıları algılama yönleri değerlendirilmektedir. Alınan yanıtların bu temaya göre değerlendirilmesi sonucunda ortaya çıkan örnekler şöyle sıralanmaktadır: "Kadınlar biraz daha sade giyinmişler, Türk kadınları gibi..." (TT83-A). "Kadınların kıyafeti ikisini daha kararlı ve güçlü gösteriyor." (AT70-A). Geçmiş deneyim temasında öğrencilerin resimler üzerinde kendi yaşanmışlıklarını bulmaları yönündeki beğenileri incelenmektedir. $\mathrm{Bu}$ tema için verilen cevapların en belirgin örnekleri şunlardır: "Su çok güzel çizilmiş, aklıma balık tuttuğum anısı geliyor." (TT120-A). "Bu resim bana büyükannemin anlattığı eski bir hikâyeyi hatırlatıyor." (AT147-B). Realizm, natüralizm temasında soru- 
lara verilen yanıtlarda gerçeklik ve doğa ile ilgili unsurların etkililiği üzerinde inceleme yapılmaktadır. Bu alan ile ilgili sıralanmış cevaplar şöyledir: "Dalgalardan dolayı su gerçek görünüyor." (AT153-A). "Su görüntüsü daha gerçekçi, daha çok doğa resmedilmiş"(TT83-A).

\section{Beşinci Soruya Ait Bulgular ve Yorumlar}
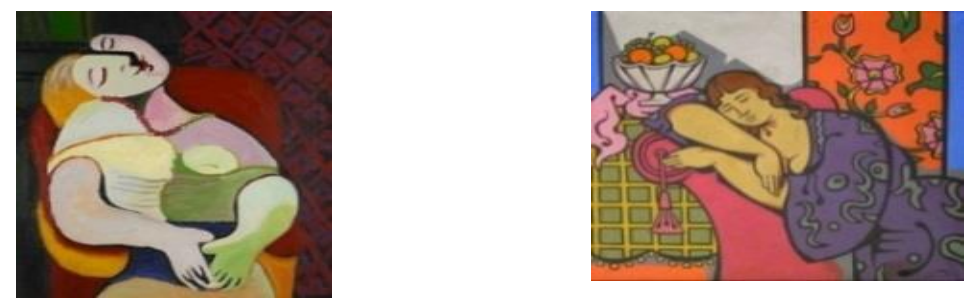

Tablo 2. Almanya'da ve Türkiye'de Yaşayan Türk Öğrencilerin Soru 5'te Batı ve Türk Sanat Eseri Tercih Dă̆ılımlarn

\begin{tabular}{|c|c|c|c|c|c|c|c|}
\hline & & & \multicolumn{2}{|c|}{ S5 } & \multirow[b]{2}{*}{ Toplam } & \multirow[b]{2}{*}{$X^{2}$} & \multirow[b]{2}{*}{$\mathbf{P}$} \\
\hline & & & Batı Sanatı & Türk Sanatı & & & \\
\hline \multirow[t]{4}{*}{ Grup } & & $\mathrm{f}$ & 76 & 82 & 158 & \multirow{6}{*}{3.928} & \multirow{6}{*}{$\begin{array}{c}.047 \\
\mathrm{P}<.05\end{array}$} \\
\hline & AT & $\%$ & 58,9 & 47,4 & 52,3 & & \\
\hline & TT & $\mathrm{f}$ & 53 & 91 & 144 & & \\
\hline & & $\%$ & 41,1 & 52,6 & 47,7 & & \\
\hline \multirow[t]{2}{*}{ Toplam } & & $\mathrm{f}$ & 129 & 173 & 302 & & \\
\hline & & $\%$ & 100 & 100 & 100 & & \\
\hline
\end{tabular}

Tablo 10 incelendiğinde Almanya'da yaşayan Türk öğrencilerle Türkiye'de yaşayan Türk öğrencilerin estetik beğenilerinde oluşan değişimde farklı bir kültürel ortamda yaşamanın etkisi olup olmadığını belirlemek amaciyla sunulan resimleri tercih etmeleri arasındaki fark istatistiksel olarak anlamlı bulunmuştur. $\left(X^{2}=3.928, P<.05\right)$

\section{Almanya'da ve Türkiye'de Yaşayan Türklerin Soru 5 Tercihlerini Etki- leyen Temel Sebepler}

Soruyu cevaplayan tüm öğrencilerin yazdıkları bu nedenlerden yola çıkarak Soru 5 için beş alanda tema oluşturulmuştur. Bunlar, renkler ve teknik; psikolojik etki; kültürel obje; kübizm ve realizm temalarıdır. 
Tablo 11. Almanya ve Türkiye'de Yaşayan Türk Öğrencilerin Soru 5'te Tercih Nedenlerine Göre Dağılımları

\begin{tabular}{|c|c|c|c|c|c|c|c|c|c|c|c|}
\hline \multicolumn{12}{|c|}{ S5 } \\
\hline & & \multicolumn{2}{|c|}{ Renkler } & \multicolumn{2}{|c|}{$\begin{array}{l}\text { Psikolojik } \\
\text { Etki }\end{array}$} & \multicolumn{2}{|c|}{ Kültürel Obje } & \multicolumn{2}{|c|}{ Kübizm } & \multicolumn{2}{|c|}{ Realizm } \\
\hline & & $\mathrm{f}$ & $\%$ & $\mathrm{f}$ & $\%$ & $\mathrm{f}$ & $\%$ & $\mathrm{f}$ & $\%$ & $\mathrm{f}$ & $\%$ \\
\hline \multirow{2}{*}{ Grup- } & $\mathrm{AT}$ & 91 & 56,9 & 74 & 46,3 & 33 & 20,6 & 46 & 28,8 & 22 & 13,8 \\
\hline & TT & 65 & 43,3 & 65 & 43,3 & 37 & 24,7 & 40 & 26,7 & 19 & 12,7 \\
\hline
\end{tabular}

Renkler ve teknik temasında Almanya ve Türkiye'deki Türk öğrencilerin resmi beğenme ve tercih etme durumunu belirleyen renkler, kullanılan teknik, içinde olduğu akım ve oluşturduğu etki üzerine yanıtlar incelenmektedir. Bu alanda cevaplar incelendiğinde şu sonuçlara varılmaktadır: "Iki insan birbirine yapıştırılmıs, sanırım birlikte duruyorlar." (AT147-A). Psikolojik etki teması içerisinde Almanya ve Türkiye'deki Türk öğrencilerin resimlerde gördükleri olay, obje ya da renklerin hissettirdikleri üzerine inceleme yapılmaktadır. "Aşk, sevgi, bir adam bir kadına arkadan sarllyyor." (AT55-A). "Seks yapmak istedikleri belli oluyor ya da sadece sevişmek istedikleri anlaşıllyor." (AT137-B). "Kişilik bölünmesi çok iyi resmedilmiş. Kolyesi çok güzel." (TT75-A). Kültürel obje temasının oluşmasını sağlayan öğrencilerden alınan değerlendirme cümleleri şöyle sıralanmaktadır: "Roma zamanların hatırlatıyor." (AT116-B). "Hiçbir fikrim yok ama meyve tabă̆ı Antik Yunan'dan kalma olabilir. Kadın da güzel duruyor." (TT148-B). Kübizm temasında öğrencilerin bilgi birikimlerine göre resimleri sanatsal anlamda değerlendirme yapmalarıyla ortaya çıkan farklılıkları incelemek amaçlanmaktadır. Bu alanın oluşturulmasını sağlayan öğrenci değerlendirme yazıları şu şekilde sıralanmıştır: "Soyut sanat daha güzel. Herkes başka bir şey görüyordur. Bence resmin derin bir hikâyesi var."(AT160-A). Realizm temasında öğrencilerin gerçeklik algılarına göre resimleri değerlendirmeleriyle ortaya çıkan farklılıkları incelemek amaçlanmaktadır. Bu alanın oluşturulmasını sağlayan öğrenci değerlendirme yazıları şu şekilde sıralanmıştır: "Canım üzüm çekti. Duvar güzel." (AT108B). "Duvardaki ve sehpadaki süsler güzel. Kadının elbisesi iyi, daha iç açıcı." (TT139-B). 


\section{Altıncı Soruya Ait Bulgular ve Yorumlar}
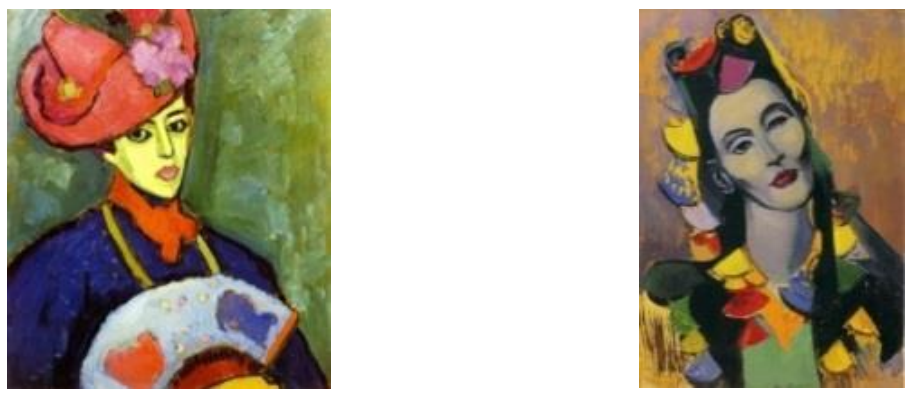

Tablo 12 incelendiğinde Almanya'da yaşayan Türk öğrencilerle Türkiye'de yaşayan Türk öğrencilerin estetik beğenilerinde oluşan değişimde farklı bir kültürel ortamda yaşamanın etkisi olup olmadığını belirlemek amaciyla sunulan resimleri tercih etmeleri arasındaki fark istatistiksel olarak anlamlı bulunmamıştır. $\left(X^{2}=.320, P>.05\right)$

Tablo 12. Almanya'da ve Türkiye'de Yaşayan Türk Öğrencilerin Soru 6'da Batı ve Türk Sanat Eseri Tercih Dağılımları

\begin{tabular}{|c|c|c|c|c|c|c|}
\hline & & \multicolumn{2}{|c|}{ S6 } & \multirow[b]{2}{*}{ Toplam } & \multirow[b]{2}{*}{$X^{2}$} & \multirow[b]{2}{*}{$\mathbf{P}$} \\
\hline & & Batı Sanatı & Türk Sanatı & & & \\
\hline \multirow{3}{*}{ Grup } & $\mathrm{f}$ & 75 & 82 & 157 & \multirow{6}{*}{.320} & \multirow{6}{*}{$\begin{array}{c}.571 \\
\mathrm{P}>.05\end{array}$} \\
\hline & $\%$ & 49,2 & 52,9 & 51,3 & & \\
\hline & $\mathrm{f}$ & 76 & 73 & 149 & & \\
\hline $\mathrm{TT}$ & $\%$ & 50,3 & 47,1 & 48,7 & & \\
\hline \multirow[t]{2}{*}{ Toplam } & $\mathrm{f}$ & 151 & 155 & 306 & & \\
\hline & $\%$ & 100 & 100 & 100 & & \\
\hline
\end{tabular}

Almanya'da ve Türkiye'de Yaşayan Türklerin Soru 6 Tercihlerini Etkileyen Temel Sebepler

Soruyu cevaplayan tüm öğrencilerin yazdıkları bu nedenlerden yola çıkarak Soru 6 için dört alanda tema oluşturulmuştur. Bunlar; renkler; kültürel motiflerden etkilenme; portre yorumlama ve gerçeklik, net ayrıntı temalarıdır. 
Tablo 13. Almanya ve Türkiye'de Yaşayan Türk Öğrencilerin Soru 6'da Tercih Nedenlerine Göre Dă̆ılımları

\begin{tabular}{|c|c|c|c|c|c|c|c|c|c|}
\hline \multicolumn{10}{|c|}{ S6 } \\
\hline & & \multicolumn{2}{|c|}{ Renkler } & \multicolumn{2}{|c|}{$\begin{array}{c}\text { Kültürel } \\
\text { Motiflerden } \\
\text { Etkilenme }\end{array}$} & \multicolumn{2}{|c|}{$\begin{array}{l}\text { Portre Yo- } \\
\text { rumlama }\end{array}$} & \multicolumn{2}{|c|}{$\begin{array}{l}\text { Gerçeklik } \\
\text { Net Ayrıntı }\end{array}$} \\
\hline & & $\mathrm{f}$ & $\%$ & $\mathrm{f}$ & $\%$ & $\mathrm{f}$ & $\%$ & $\mathrm{f}$ & $\%$ \\
\hline \multirow{2}{*}{ Grup } & AT & 100 & 62,5 & 66 & 41,3 & 110 & 68,8 & 43 & 26,9 \\
\hline & TT & 83 & 55,3 & 68 & 45,3 & 106 & 70,7 & 31 & 20,7 \\
\hline
\end{tabular}

Renkler temasında Almanya ve Türkiye'de yaşayan Türk öğrencilerin resmi beğenme ve tercih etme durumunu belirleyen renkler ve oluşturduğu etki üzerine yantlar incelenmektedir. Bunun gibi renkler temasinın oluşmasını sağlayan cevaplar incelendiğinde şu sonuçlara varılmaktadır: "Çok fazla renk yok böylece figürün yüzünden başka bir yere bakamıyorum. Dikkatim dă̆ılmıyor." (AT145-A). "Picasso'nun resimlerine benzediği için beğendim." (TT68-A). Kültürel motiflerden etkilenme temasında Almanya ve Türkiye'de yaşayan Türk öğrencilerin resimler üzerinde kültürel simgeleri fark etmesi ile bunlar üzerine yapılan değerlendirmeler incelenmektedir. Bu temanın oluşmasını sağlayan öğrencilerden alınan değerlendirme cümleleri şöyle sıralanmaktadır: "Çin kültürünü hatırlatıyor." (AT149-B). "Rio de Jenerio'yu (karnavaldan dolayı) hatırlattı." (AT121B). "Bana Misirliları hatırlattı." (AT123-B). "Asyalı simgeler var." (AT83-B). Geleneksel motiflerin varlığında ve eski bir kültür örneği olduğunda ayn fikirde olan öğrenciler bu motiflerin hangi kültüre ait olduğunu kendi ilgilerine göre değerlendirmektedir. Bu nedenle aynı resme bakan her öğrenci farklı fikirler sunmaktadır. "Bana Türk bir oyuncuyu hatırlatıyor." (AT135-A). Portre yorumlama temasinda resimdeki portrelerin rengi, ifadeleri ile ilgili etkilenme; benzetmelerle oluşan duygusal çözümlemeler incelenmektedir. Bu temayı oluşturan öğrenci cevapları şöyle sıralanmaktadır: "Michael Jackson'a benziyor." (AT157-B). Hintli bir kadına ya da Michael Jackson'a benzetilmektedir. "Turist gibi duruyor. Benim için kırmızı şapka çok güzel. Kadın iyi gibi duruyor." (TT149-A). A resmindeki figürün kıyafetinden ve duruşundan dolayı asil, kültürlü ve zengin olarak düşünülmektedir. Kendine güvenen bir kadın ve diğer resimle kıyas- 
lanarak daha dişi bir görüntü sergilediği ifade edilmiştir. Gerçeklik, net ayrıntı temasında öğrencilerin resimler üzerindeki ayrıntılara dikkat edip bunları yorumlamalarıyla elde edilen veriler incelenmektedir. Bunun sonucunda ortaya çıkan yanıtları şöyle sıralayabiliriz: "Kıyafetindeki ayrintılar yüzünü biraz yok ediyor." (AT103-B). "B resminde yüz hatlar ve gölgelendirmeler gerçekçi. B resmi sanki 19 Mayıs, 23 Nisan törenlerini anımsatıyor." (TT78-B). Türkiye'de yaşayan Türk öğrencilerden biri bu resmi renkli süslerden ve kıyafetten dolayı milli bayramlara benzetmiştir.

\section{Yedinci Soruya Ait Bulgular ve Yorumlar}
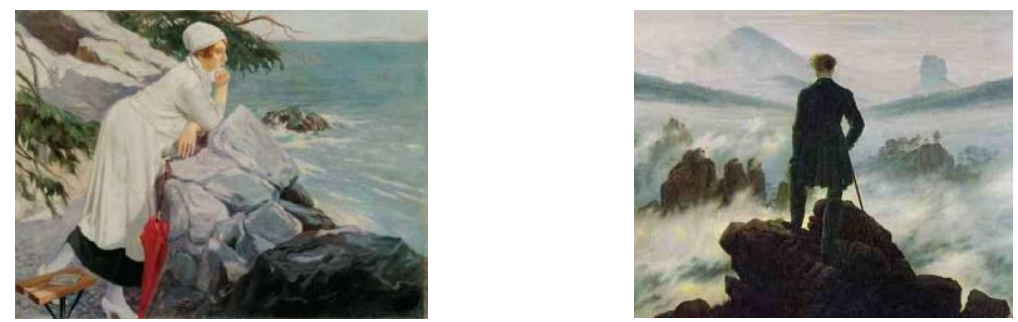

Tablo 14. Almanya'da ve Türkiye'de Yaşayan Türk Öğrencilerin Soru 7'de Batı ve Türk Sanat Eseri Tercih Dă̆ılımları

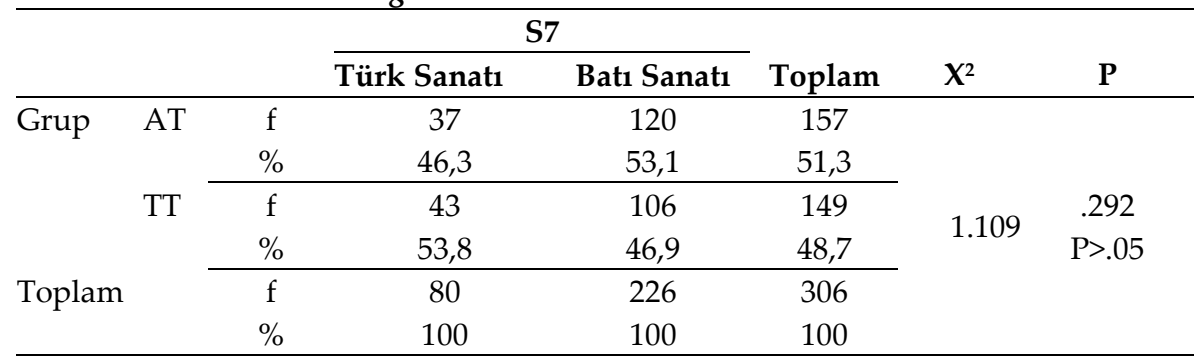

Tablo 14 incelendiğinde Almanya'da yaşayan Türk öğrencilerle Türkiye'de yaşayan Türk öğrencilerin estetik beğenilerinde oluşan değişimde farklı bir kültürel ortamda yaşamanın etkisi olup olmadığını belirlemek amaciyla sunulan resimleri tercih etmeleri arasındaki fark istatistiksel olarak anlamlı bulunmamıştır. $\left(X^{2}=1.109, P>.05\right)$ 


\section{Almanya'da ve Türkiye'de Yaşayan Türklerin Soru 7 Tercihlerini Etki- leyen Temel Sebepler}

Soruyu cevaplayan tüm öğrencilerin yazdıkları bu nedenlerden yola çıkarak Soru 7 için beş alanda tema oluşturulmuştur. Bunlar, obje yorumlama ve his edinme; manzara, empresyonizm; realizm; geçmiş deneyim hatırlatma; bakış açısı, perspektif temalarıdır.

Tablo 3. Almanya ve Türkiye'de Yaşayan Türk Öğrencilerin Soru 7'de Tercih Nedenlerine Göre Dağılımları

\begin{tabular}{|c|c|c|c|c|c|c|c|c|c|c|c|}
\hline \multicolumn{12}{|c|}{ S7 } \\
\hline & & \multicolumn{2}{|c|}{$\begin{array}{l}\text { Obje } \\
\text { Yorumlama } \\
\text { His Edinme }\end{array}$} & \multicolumn{2}{|c|}{$\begin{array}{l}\text { Manzara } \\
\text { Empresyo- } \\
\text { nizm }\end{array}$} & \multicolumn{2}{|c|}{ Realizm } & \multicolumn{2}{|c|}{$\begin{array}{c}\text { Geçmiş ve } \\
\text { Bilgi Dene- } \\
\text { yimi Hatırla- } \\
\text { ma }\end{array}$} & \multicolumn{2}{|c|}{$\begin{array}{l}\text { Bakış Açısı } \\
\text { Perspektif }\end{array}$} \\
\hline & & $\mathrm{f}$ & $\%$ & $\mathrm{f}$ & $\%$ & $\mathrm{f}$ & $\%$ & $\mathrm{f}$ & $\%$ & $\mathrm{f}$ & $\%$ \\
\hline \multirow{2}{*}{ Grup } & AT & 104 & 65 & 115 & 71,9 & 26 & 16,3 & 40 & 25 & 69 & 43,1 \\
\hline & TT & 133 & 88,7 & 109 & 72,7 & 32 & 21,3 & 40 & 26,7 & 47 & 31,3 \\
\hline
\end{tabular}

Çevresel Etkenleri Yorumlama ve His Edinme teması içerisinde Almanya ve Türkiye'de yaşayan Türk öğrencilerin resimlerde gördükleri çevre ile içinde olan figür, figürün duruşu ve kompozisyona dahil olan diğer ögelerini yorumlama ve hissettirdiği duygu incelenerek analiz edilmektedir. Bu temayı oluşturan yanıtlar incelendiğinde şu örneklere yer verilmiştir: "Adam her şeye hâkim gibi bakıyor ama bir problemi var, dalgalar da adamın hissettiği gibi görünüyor, üzücü, kızgın, öfkeli." (AT160-B). "Bir kahramanı anlatıyor gibi. Sanki kazanmış ve kazandıklarına bakıyor. Bu resim daha güzel." (TT61-B). Manzara, empresyonizm temasında resmin yansıttığı çevre ve içinde bulunan nesnelerin olay ve olgularla bağlantısını kuran yorumlar incelenmektedir. Bu alanın oluşmasını sağlayan belirleyici örnekler şu şekilde sıralanmaktadır: "Muhteşem şelale, çă̆layan var." (AT158-B). "Dă̆ın zirvesinde çımış seyrediyor. Orada ben de olmak isterdim. Eve gidince ben de bu resimden çizeceğim." (TT145-B). Resim dağın zirvesinde bir görüntüyü yansıtmasından dolayı heyecan yaratmaktadır. Realizm temasında öğrencilerin resimler üzerindeki ayrıntılara ve gerçek görünümlere dikkat edip bunları yorumlamalarıyla elde edilen veriler 
incelenmektedir. Almanya'da ve Türkiye'de yaşayan Türk öğrencilerin A ve B resimlerini tercihlerindeki realizmi algı farklı detaylara yönelmektedir. "Renkleri güzel. Köylerde duran kızlara benziyor." (TT121-A). Geçmiş deneyim hatırlatma temasında resmin daha önceki yaşanmışlıklarla ilişki kurularak olay ve olguların aşina gelmesi durumunda ortaya çıan beğeni tepkileri incelenip değerlendirilmektedir. "Bana bir diziyi hatırlatıyor. Hz. Muhammed'in dağa çıkışını hatırlatıyor. Bana özgürlü̈̆̈̈ gösteriyor ve rahatlatıyor." (AT140-A). "Resimdeki insan Atatürk'e benziyor. Yenilmezlik ruhu anlatılmaya çalışılmış." (TT5-B). Türkiye'de yaşayan Türk öğrencilerin B resmini tercih edenlerin sayılarının fazla olmasına rağmen beğenme nedenine bakıldığında böyle bir bilgi birikiminden söz etmek mümkün olmamaktadır. Beğenme sebeplerinin geneli Türk milletinin lideri Atatürk'e benzetimdir. Resimlerin siyasi güç anlatımına dikkat çeken Duncum (2005:115), görsel eserlerin sadece inanç ve değerleri yansıtmayan ayn zamanda sosyal amaç ve fikirlerin yapılanmasını sağlayan bir güç de olduğunu ifade etmektedir. Bakış açısı, perspektif temasında resmin arka planındaki derinlik, resmin genelindeki görüntü, figürün içinde bulunduğu mekân üzerine yapılan değerlendirmeler incelenmektedir. Bu alanın oluşmasında verilen cevapların en belirgin örnekleri şöyle sıralanmaktadır: "Arkadan bakış daha iyi görünüyor, çünkü böylece tüm resim görüş alanında olmuş oluyor." (AT64-B). "Kadının suyu seyretmesi hoşuma gitti. Kadının olduğu yer çok güzel." (TT120-A). A resmini beğenen Türkiye'de bulunan Türk öğrenciler ise figürün denizi izlemesini ve düşünmesini ve şemsiyenin resmi renklendirmesini beğenmişlerdir.

\section{Sekizinci Soruya Ait Bulgular ve Yorumlar}
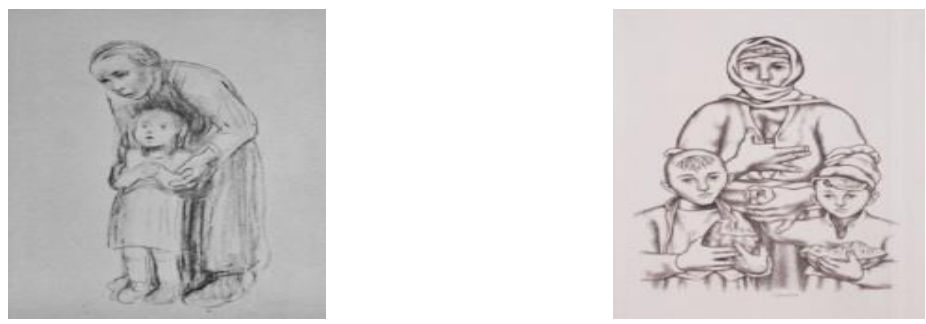
Tablo16. Almanya'da ve Türkiye'de Yaşayan Türk Öğrencilerin Soru 8'de Batı ve Türk Sanat Eseri Tercih Dă̆ılımları

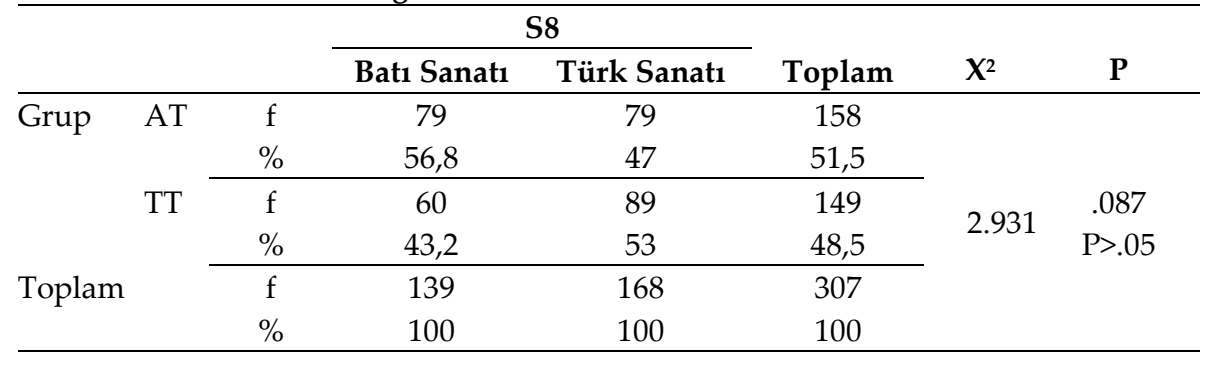

Tablo 16 incelendiğinde Almanya'da yaşayan Türk öğrencilerle Türkiye'de yaşayan Türk öğrencilerin estetik beğenilerinde oluşan değişimde farklı bir kültürel ortamda yaşamanın etkisi olup olmadığını belirlemek amaciyla sunulan resimleri tercih etmeleri arasındaki fark istatistiksel olarak anlamlı bulunmamıştır. $\left(X^{2}=2.931, P>.05\right)$

\section{Almanya'da ve Türkiye'de Yaşayan Türklerin Soru 8 Tercihlerini Etki- leyen Temel Sebepler}

Soruyu cevaplayan tüm öğrencilerin yazdıkları bu nedenlerden yola çıkarak Soru 8 için dört alanda tema oluşturulmuştur. Bunlar, figürden duygu edinme ve etkilenme; teknik; gerçekçilik ve detay; kültürel sembol ve deneyim hatırlatma; temalarıdır.

Tablo17. Almanya ve Türkiye'de Yaşayan Türk Öğrencilerin Soru 8'de Tercih Nedenlerine Göre Dă̆ılımları

\begin{tabular}{cccccccccc}
\hline & \multicolumn{1}{c}{ S8 } & $\begin{array}{c}\text { Figürden } \\
\text { Duygu } \\
\text { Edinme Etki- } \\
\text { lenme }\end{array}$ & Teknik & \multicolumn{2}{c}{$\begin{array}{c}\text { Gerçekçilik } \\
\text { Detay }\end{array}$} & $\begin{array}{c}\text { Kültürel Sem- } \\
\text { bol } \\
\text { Deneyim } \\
\text { Hatırlatma }\end{array}$ \\
\hline & f & $\%$ & f & $\%$ & f & $\%$ & f & $\%$ \\
\hline Grup & AT & 132 & 82,5 & 49 & 30,6 & 43 & 26,9 & 60 & 37,5 \\
\hline & TT & 127 & 84,7 & 54 & 36 & 27 & 18 & 56 & 37,3 \\
\hline
\end{tabular}

Figürden duygu edinme ve etkilenme temasında resimde çizgisel üslupla kara kalem tekniğiyle çizilmiş resimlerdeki figürlerin öğrencilerin 
kendilerine yakın gelen ya da kendilerini etkileyen tarafları belirleyecek şekilde incelenmektedir. Bu temayı oluşturan en belirgin örnekleri şu şekilde sıralamak mümkündür: "Yaşamak gerektiğgini ve bir şeye ulaşmak için savaşmak gerektiğini gösteriyor. Umudu gösteriyor, yoksulluğu anlatıyor." (AT127-A). "Ailenin önemini gösteriyor. Hepsi korkmuş ve üzgün bakınıyor. $B u$ durum insanın içine dokunuyor. Yemek bazı insanların fakirliğini gösteriyor." (AT16-B). Almanya'daki Türk öğrenciler, A resmini fakirlik içindeki insanların durumu yönünden ele almışlardır. Toplumsal mutluluğu sağlamak için kurulması gereken denge, umut ve yoksulluk örneğiyle sosyolojik anlamda değerlendirilmektedir. "Sanki bir annenin kızını koruması. Çok duygusal bir resim. Sanki annesi çocuğuna namaz kılmayı öğretiyor." (TT126-A). Verilen bu cevaptan Batı sanat eseri olan A resminin dini açıdan bir değerlendirilmesinin yapıldığı anlaşılmaktadır. Figürün duruşu namaz kılmaya benzetilmektedir. Teknik temasında resimlerin üslupları ve kullanılan materyallerden oluşan anlatımdan etkilenme ile ilgili veriler incelenmektedir. "Resmin kara kalem ile çizilmesi ilgimi çekti. Sanatçı orada bir anne ile çocuğunun sevgisini anlatmış." (TT137-A). Gerçekçilik ve detay temasında resimlerde kullanılan figür ya da objelerin konu ve kompozisyona uygunluğu, realist görünümü ve ayrıntının kullanılmasindaki etkililik üzerine verilen yantlar incelenmektedir. Bu alanın oluşmasını sağlayan öğrenci görüşleri şu şekilde sıralanmaktadır: "Çocuğun elindeki karpuz ve ekmek dikkatimi çekti. Kadının elini yeleğinin içine sokması dikkatimi çekti." (TT120-B). Kültürel sembol temasında resimlerde bulunan kültürü yansıtan ayrıntıların algılanıp algılanmaması ve bununla ilgili beğeniler konusunda yapılan açıklamalar incelenmektedir. "Anadolu, geleneksellik." (AT36-B). Almanya'da yaşayan Türk öğrencilerin B resmini tercih etmelerindeki nedenleri geleneksel ayrıntıları fark etmeleri ve Anadolu'yu hatırlamalarıdır. Türkiye'de yaşayan Türk öğrenciler B resmini değerlendirirken de Almanya'daki Türk öğrenciler gibi Türk kültürünü yansıtan değerlere dikkat etmişlerdir. "Namaz kılmayı öğretiyor. Bir anne ve çocuğu var. Kara kalem resmi seviyorum." (TT95-A). Deneyim hatırlatma temasında öğrencilerin resimler üzerinde kendi yaşanmışlıklarını bulmaları yönündeki beğenileri incelenmektedir. Bu alanda verilen cevaplardan Almanya'da yaşayan Türk öğrencilerin ve Türkiye'de yaşayan Türk öğrencilerin deneyimlerindeki farklılıkların boyutları ve etkilendikleri olgular anlaşılmaya çalışılmaktadır. Bu tema için veri- 
len cevapların en belirgin örnekleri şunlardır: Kendime yakın hissettim. Kadın çocuklarıyla bana Türkiye'de bir yakınımızı hatırlattı." (AT26-B). Bazı öğrencilere göre köyde yaşayan insanları ya da akrabaları hatırlatmaktadır. Çocukluğunu hatırlattığını söyleyen öğrenciler Türkiye'yi hatırlattığı için kendilerini resme yakın hissetmişlerdir.

\section{Dokuzuncu Soruya Ait Bulgular ve Yorumlar}
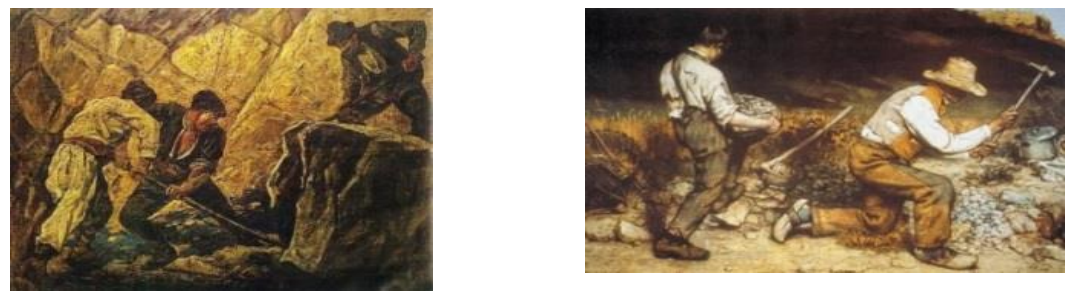

Tablo18. Almanya'da ve Türkiye'de Yaşayan Türk Öğrencilerin Soru 9'da Batı ve Türk Sanat Eseri Tercih Dă̆ılımları

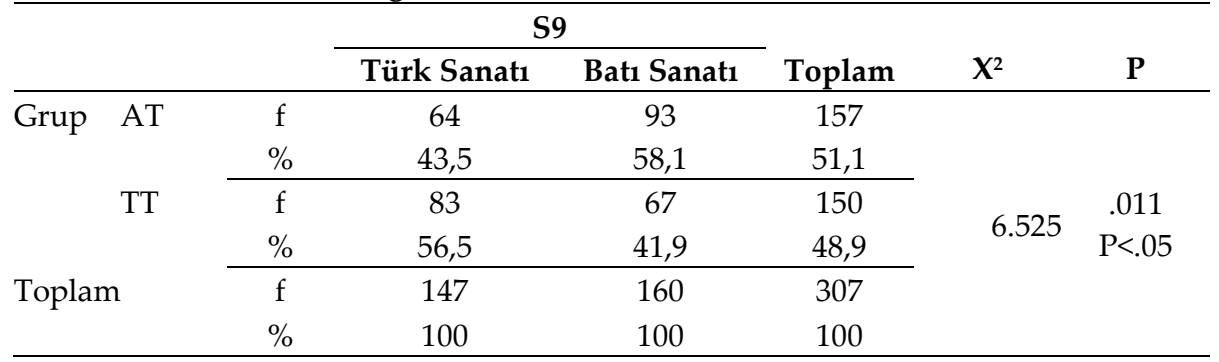

Tablo 18 incelendiğinde Almanya'da yaşayan Türk öğrencilerle Türkiye'de yaşayan Türk öğrencilerin estetik beğenilerinde oluşan değişimde farklı bir kültürel ortamda yaşamanın etkisi olup olmadığını belirlemek amaciyla sunulan resimleri tercih etmeleri arasındaki fark istatistiksel olarak anlamlı bulunmuştur. $\left(X^{2}=6.525, P<.05\right)$ 


\section{Almanya'da ve Türkiye'de Yaşayan Türklerin Soru 9 Tercihlerini Etki- leyen Temel Sebepler}

Soruyu cevaplayan tüm öğrencilerin yazdıkları bu nedenlerden yola çıkarak Soru 9 için dört alanda tema oluşturulmuştur. Bunlar, konu, realizm, renk ve kültürel değerlendirme deneyim hatırlatma temalarıdır.

Tablo 4. Almanya ve Türkiye'de Yaşayan Türk Öğrencilerin Soru 9'da Tercih Nedenlerine Göre Dă̆ılımları

\begin{tabular}{|c|c|c|c|c|c|c|c|c|c|}
\hline \multicolumn{10}{|c|}{ S9 } \\
\hline & & \multicolumn{2}{|c|}{ Konu } & \multicolumn{2}{|c|}{ Realizm } & \multicolumn{2}{|c|}{ Renk } & \multicolumn{2}{|c|}{$\begin{array}{c}\text { Kültürel Değer } \\
\text { lendirme } \\
\text { Deneyim } \\
\text { Hatırlatma }\end{array}$} \\
\hline & & $\mathrm{f}$ & $\%$ & $\mathrm{f}$ & $\%$ & $\mathrm{f}$ & $\%$ & $\mathrm{f}$ & $\%$ \\
\hline \multirow{2}{*}{ Grup } & $\mathrm{AT}$ & 89 & 55,6 & 69 & 43,1 & 80 & 50 & 36 & 22,5 \\
\hline & TT & 99 & 66 & 59 & 39,3 & 61 & 40,7 & 39 & 26 \\
\hline
\end{tabular}

Konu temasında resimde işlenen konu, vurgulanmak istenen düşünceye bağlı algılanan içerik ve verilen mesajı kültürel algı çerçevesinde algılandığını belirten görüşler analiz edilmektedir. Bu alanın oluşmasını sağlayan öğrenci görüşleri şöyle sıralanmıştır: "Hedef için çabalamayı gösteriyor." (AT127-A). "Insanlar daha çok azimle çalışıyor. Daha zorlu şartlarda çalışıyorlar." (TT82-A). "Kovboy filmlerine benziyor. Maden arıyorlar." (TT142-B). Öğrenciler kovboy filmlerinde maden işçilerinin çalışmasını konu olarak belirlemiş̧lerdir. Realizm temasında resimlerin gerçekliği, figür ya da objelerdeki ayrıntıları, olay örüntülerinin gerçek olaylarla örtüşmesi durumlarının değerlendirilerek yapıldığı tercihler analiz edilmektedir. Bu alanı oluşturan cevaplardan belirgin olanları şu şekilde sıralanmıştır: "Figürlerin pozisyonu, zorluk, mecburiyet ve çalışmayı simgeliyor." (AT41-B). "Adamın çorabı kokuyor. Elindekiler işe yaramaz." (TT141-B). Resimdeki figürün çok çalışan bir işçi olması dolayısıyla ayak kokusunu duyduğunu söyleyen öğrenci, resmin gerçekliğinin güçlü olduğu yönüne vurgu yapmıştır. Renk temasında resimlerde kullanılan renkler ve tonlarının resimlerin konuları ile bütünlüğü sağlama durumları ve renklerin hissettirdiği duyguları ortaya çıarmayı amaçlayan analizler yapılmaktadır. Bu alanı oluşturan Almanya'da ve Türkiye'de olan Türk 
öğrenci cevaplarından en belirleyici olanlar şu şekilde sıralanmıştır: "Resimde çalışan adamlar yorgun görünüyorlar. Bu durum iş hayatının ne kadar zor olduğunu gösteriyor. Koyu olan renkler üzgün ve değersiz bir ortam yarattyor." (AT31- $A$ ). Kültürel değerlendirme deneyim hatırlatma temasında resimlerde yaşanan olayın günlük hayatta ya da daha öncesinde yaşanmış bir olay ya da deneyimi hatırlatıcı etkenler araştırılmaktadır. Bu alanla ilgili analiz edilen öğrenci cevapları şu şekilde sıralanmıştır: " $O$ zamanın kararlı insanların gösteriyor." (AT127-A). "Soma faciasını hatırlatıyor. Hayatın gerçekliğini ve zorluğunu belirtiyor. Yardımlaşmayı anlatıyor." (TT78-A). ). "1 Mayıs İşçi Bayramı. Ekmek parası için çalışıyor. Alın teri görüyorum." (TT15-A). Bu dönemde Türkiye'de Soma'da yaşanan maden kazası olaylarından dolayı A resminin Almanya ve Türkiye'deki Türk öğrenciler tarafından Soma'ya benzetilmesi göze çarpmaktadır.

\section{Onuncu Soruya Ait Bulgular ve Yorumlar}
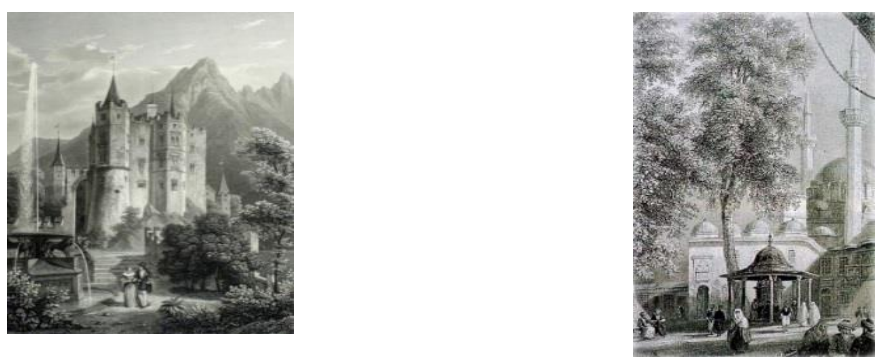

Tablo 20 incelendiğinde Almanya'da yaşayan Türk öğrencilerle Türkiye'de yaşayan Türk öğrencilerin estetik beğenilerinde oluşan değişimde farklı bir kültürel ortamda yaşamanın etkisi olup olmadığını belirlemek amaciyla sunulan resimleri tercih etmeleri arasındaki fark istatistiksel olarak anlamlı bulunmamıştır. $\left(X^{2}=1.883, P>.05\right)$ 
Tablo 5. Almanya'da ve Türkiye'de Yaşayan Türk Öğrencilerin Soru 10'da Batı ve Türk Sanat Eseri Tercih Dă̆ılımları

\begin{tabular}{|c|c|c|c|c|c|c|c|}
\hline & & & \multicolumn{2}{|c|}{$\mathrm{S} 10$} & \multirow[b]{2}{*}{ Toplam } & \multirow[b]{2}{*}{$X^{2}$} & \multirow[b]{2}{*}{$\mathbf{P}$} \\
\hline & & & Batı Sanatı & Türk Sanatı & & & \\
\hline \multirow[t]{4}{*}{ Grup } & $\mathrm{AT}$ & $\mathrm{f}$ & 47 & 110 & 157 & \multirow{6}{*}{1.883} & \multirow{6}{*}{$\begin{array}{c}.170 \\
\mathrm{P}>.05\end{array}$} \\
\hline & & $\%$ & 45,6 & 53,9 & 51,1 & & \\
\hline & TT & $\mathrm{f}$ & 56 & 94 & 150 & & \\
\hline & & $\%$ & 54,4 & 46,1 & 48,9 & & \\
\hline \multirow{2}{*}{\multicolumn{2}{|c|}{ Toplam }} & $\mathrm{f}$ & 103 & 204 & 307 & & \\
\hline & & $\%$ & 100 & 100 & 100 & & \\
\hline
\end{tabular}

Almanya'da ve Türkiye'de Yaşayan Türklerin Soru 10 Tercihlerini Etkileyen Temel Sebepler

Soruyu cevaplayan tüm öğrencilerin yazdıkları bu nedenlerden yola çıkarak Soru 10 için altı alanda tema oluşturulmuştur. Bunlar, dinsel ve kültürel sembol; manzara; tarihsel değer, geçmiş deneyim hatırlatma; duyusal etkilenme; netlik, realizm; teknik temalarıdır.

Tablo 21. Almanya ve Türkiye'de Yaşayan Türk Öğrencilerin Soru 10'da Tercih Nedenlerine Göre Dă̆glımları

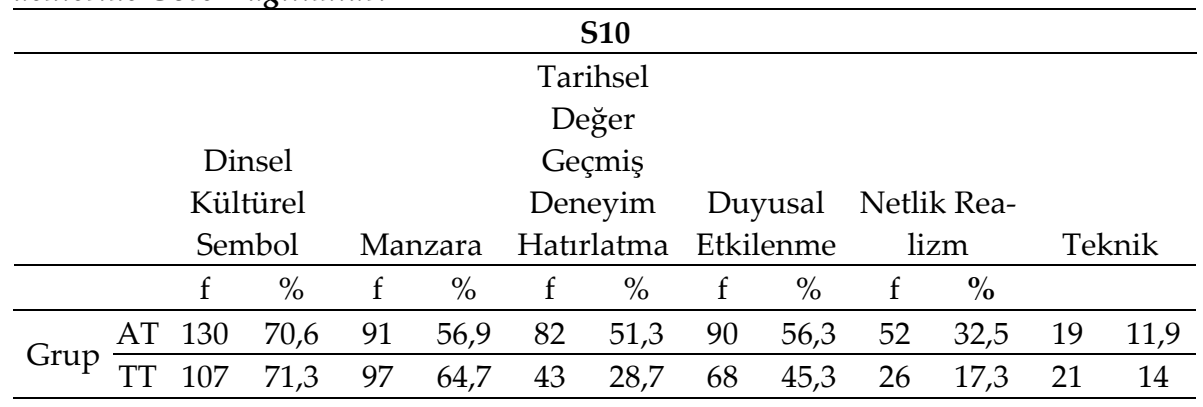

Dinsel ve kültürel sembol temasında resimlerde görülen dinsel figür, obje, olay ve olguların algılanması sonucunda ortaya çıkan beğeni ya da tercih nedenleri analiz edilmektedir. Bu alanın oluşmasını sağlayan verilerden en belirgin olanları şöyle sıralanmaktadır: "Resimdeki minareler bana memleketimi hatırlatıyor. Sanki daha önce bulunduğum bir yer gibi geliyor." (AT5-B). "Çünkü bir cami var. Konturlar çok güzel, geleneksel görünüyor." (AT15-B). Almanya'da yaşayan Türk öğrenciler B resmini tercih 
ederken dikkat edilen nokta cami görüntüsünün olmasından dolayı Türkiye'yi anımsatmasıdır. Resmin sahip olduğu içeriğin ezanı anımsatması, orada olmayı istemek, İstanbul'u hatırlatması arka planda dinsel figüre bağlı vatan özleminin yansımasıdır. "Mekke." (AT143-B), şeklinde tek kelime ile beğenisini ifade etmektedir. "Mükemmel kilise ya da kale, saray." (AT157- $A$ ). A resmini beğenen Almanya'da yaşayan Türk öğrenci için kilise ya da kale mükemmel görünmektedir. Manzara temasında resimde görülen arka planda yer alan objeler, mekân ve çevrenin beğeni oluşturacak özellikleri verilen cevaplarla analiz edilmektedir. Bu alanı oluşturan en belirgin cevaplar şu şekilde sıralanmaktadır: "Gökyüzü, dă̆lar, saray ve şato." (AT31-A). "Şato var, bahçede sevgililer geziyor. Su fiskiyesi var." (TT142-A). A resmini tercih eden Almanya'da ve Türkiye'deki Türk öğrencilerin verdikleri yanıtlardan daha çok şato ve manzaranın eski dönemleri hatırlattığı için beğenildiği anlaşılmaktadır. Tarihsel değer, geçmiş deneyim hatırlatma temasında öğrencilerin resimler üzerinde kendi yaşanmışlıklarını bulmaları yönündeki beğenileri incelenmektedir. Bu tema için verilen cevapların en belirgin örnekleri şunlardır: "Camiler çok güzel, içimde anılar, hatıralar uyandırıyor. Camiye ilk ziyaretimde anneannem beni namaz kllmaya götürmüştü." (AT121-B). Duyusal etkilenme temasinda resimlerin içeriklerini oluşturan ve izleyiciyi etkileyen dini unsurların ya da kültürel çevrenin tüm gerçekliğiyle sunulmasıyla ortaya ç1kan duygu yoğunluğu analiz edilmektedir. Farklılıkları ortaya çıkaran öğrenci cevaplarından en belirgin olanları şöyle sıralanmaktadır: "Sıcak huzur verici." (AT36-B). "Sultan Ahmet Camii'ne gitmek istediğim için, orada namaz kılmak istediğim için ve orada abdest almak istediğim için bu resmi beğendim." (TT146-B). Netlik, realizm temasında resimlerde kullanılan figür ya da objelerin konu ve kompozisyona uygunluğu, realist görünümü ve ayrıntının kullanılmasındaki etkililik üzerine verilen yanıtlar incelenmektedir. Bu alanın oluşmasını sağlayan öğrenci görüşleri şu şekilde sıralanmaktadır: Kalenin detaylandırılması." (AT72-A). "Cami çizilmiş, geleneksel bir çarşıda günlük bir sahne, çok temiz ve net çizilmiş." (AT78-B). Teknik temasında resimlerin üslupları ve kullanılan materyallerden oluşan anlatımdan etkilenme ile ilgili veriler incelenmektedir. Bu alanı oluşturan cevaplar şu şekilde sıralanmaktadır: "Kalenin gölgelendirilmesi, bir masal gibi." (AT79-A). "Kara kalem harika olmuş. Cami çok güzel." (TT131-B). 
On Birinci Soruya Ait Bulgular ve Yorumlar
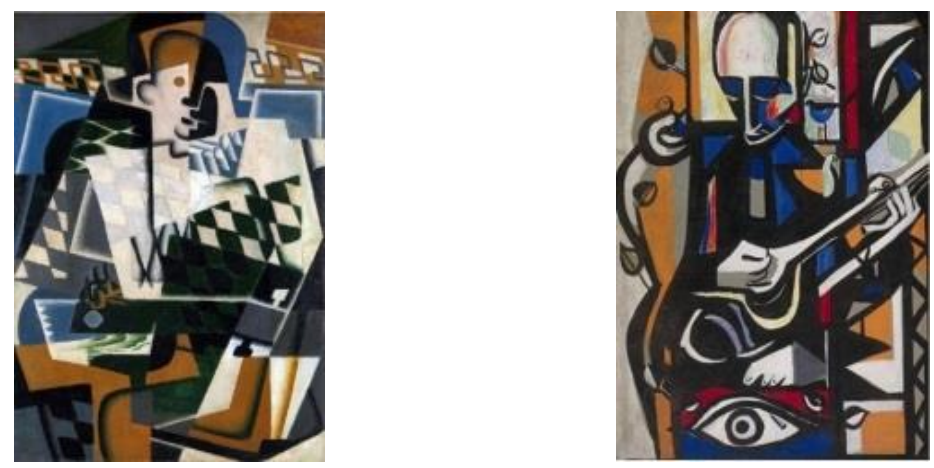

Tablo 22. Almanya'da ve Türkiye'de Yaşayan Türk Öğrencilerin Soru 11'de Batı ve Türk Sanat Eseri Tercih Dağılımları

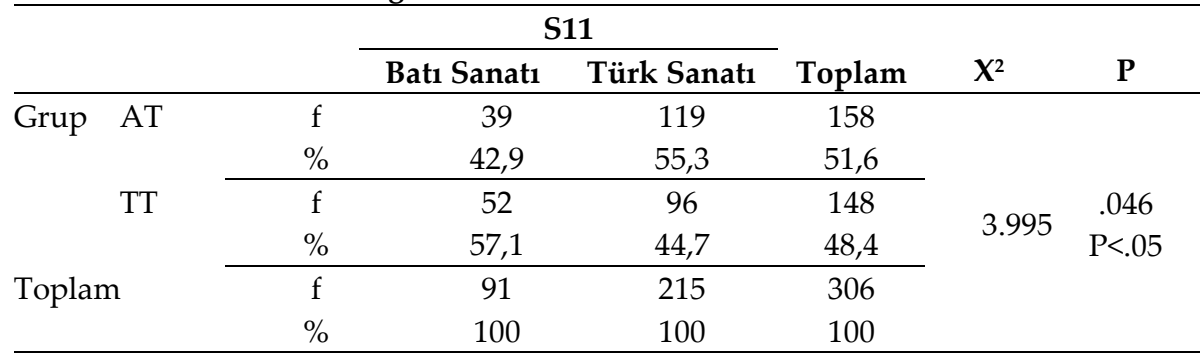

Tablo 22 incelendiğinde Almanya'da yaşayan Türk öğrencilerle Türkiye'de yaşayan Türk öğrencilerin estetik beğenilerinde oluşan değişimde farklı bir kültürel ortamda yaşamanın etkisi olup olmadığını belirlemek amaciyla sunulan resimleri tercih etmeleri arasındaki fark istatistiksel olarak anlamlı bulunmuştur. $\left(X^{2}=3.995, P<.05\right)$

\section{Almanya'da ve Türkiye'de Yaşayan Türklerin Soru 11 Tercihlerini Etkileyen Temel Sebepler}

Soruyu cevaplayan tüm öğrencilerin yazdıkları bu nedenlerden yola çıkarak Soru 11 için dört alanda tema oluşturulmuştur. Bunlar, kültürel semboller; renk; kübizm ve şekiller; geçmiş deneyim, duygu edinme temalarıdır. 
Tablo 23. Almanya ve Türkiye'de Yaşayan Türk Öğrencilerin Soru 11'de Tercih Nedenlerine Göre Dă̆̆lımları

\begin{tabular}{|c|c|c|c|c|c|c|c|c|c|}
\hline \multicolumn{10}{|c|}{ S11 } \\
\hline & & \multicolumn{2}{|c|}{$\begin{array}{l}\text { Kültürel } \\
\text { Semboller }\end{array}$} & \multicolumn{2}{|c|}{ Renk } & \multicolumn{2}{|c|}{$\begin{array}{l}\text { Kübizm } \\
\text { Şekiller }\end{array}$} & \multicolumn{2}{|c|}{$\begin{array}{c}\text { Geçmiş } \\
\text { Deneyim, Duy- } \\
\text { gu Edinme }\end{array}$} \\
\hline & & $\mathrm{f}$ & $\%$ & $\mathrm{f}$ & $\%$ & $\mathrm{f}$ & $\%$ & $\mathrm{f}$ & $\%$ \\
\hline \multirow{2}{*}{ Grup } & AT & 76 & 47,5 & 76 & 47,5 & 65 & 40,6 & 35 & 21,9 \\
\hline & TT & 79 & 52,7 & 69 & 46 & 71 & 47,3 & 44 & 29,3 \\
\hline
\end{tabular}

Kültürel semboller temasında kübizmin etkisinde yapılmış resimde yer alan kültürel objelerin fark edilip yorumlanmasında ortaya çıkan cevaplar analiz edilmektedir. Farklı motiflerin düzenlendiği resimlerdeki her iki figürün içinde bulundukları şekil ve simgeler yorumlamalarla açıklanmaktadır. Açıklamaların sonucunda kültürel farklılığın anlaşılmasındaki oranlar ve çıarımlar üzerine sonuçlara varılmıştır. Bu alanı oluşturan cevapların en belirgin olanları şu şekilde sıralanmıştır: "Caz müzik ve Bob Marley, illuminati." (AT149-B). "Türk gitarm hatırlatıyor." (AT65-B). "Bă̆lama çalıyor." (TT124-B). "Bana Âşık Veysel'i hatırlattı." (TT33-B). Almanya'da yaşayan Türk öğrencilerin yorumlarına bakıld1ğında tercihlerde daha çok popüler kültürün ve Türk kültürünün etkisinin olduğu gözlenmektedir. Renk temasında resimlerde bulunan renklerden duyulan his ya da farklı benzetimlerden dolayı edinilen yarg1 konusunda ortaya çıkan görüşler analiz edilmektedir. Bu alanın oluşmasinda dikkat çeken sunumlar şöyle siralanmaktadır: "Tek tonda olduğu için hüzünlü görünüyor. Çok belirli değil ama kibirli duruyor." (AT98-A). A resmini tercih eden Almanya'daki Türk öğrenciler renk tonlarının hep aynı olmasından dolayı resimde hüzün hissetmektedirler. Ayrıca figürün gerçekçi olmayan bir resimde belirgin hissedilmesi öğrencilerin hoşuna gitmiştir. "Renkleri çok güzel bir atmosfer yaratıyor. Saz veya başka bir enstrüman çaldığın gösteriyor. Rock müziği akla getiriyor. Gözlerin siyah olması, üzüntüyü ve yalnızlığı anımsatıyor." (AT31-B). Renklerin canlıllğı, figürün elinde enstrüman oluşu rock gibi popüler müziği akla getirmiştir. Kübizm ve şekiller temasında resimlerde bulunan şekillerden ve kübizm akımından duyulan his ya da farklı benzetimlerden dolayı edinilen yarg1 konusunda ortaya çıan görüşler analiz edilmektedir. Bu alanın oluşmasında dikkat çeken sunumlar şöyle sıralanmaktadır: "Poker kartını 
hatırlattı. Düzgün ve güzel çizgiler üç boyutlu görünüyor (mekân)." (AT82-A). "Kendi sanatımızdan ve geleneklerimizden izler görüyorum. Eşsiz bir kübizm örneği." (TT15-B). Türkiye'de yaşayan Türk öğrenciler B resminin Türk sanatına ait bir eser olduğunun ve Türk kültürünü yansıttığının farkına varmaktadır. Geçmiş deneyim, duygu edinme temasında resimlerde yaşanan olayın günlük hayatta ya da daha öncesinde yaşanmış bir olay ya da deneyimi hatırlatıcı etkenleri araştırılmaktadır. Bu alanla ilgili analiz edilen öğrenci cevapları şu şekilde sıralanmaktadır: "Sazın, bağlamanın güzel sesini gösteriyor. Müziğin anlamını gösteriyor. Ülkemi ve babamı hatırlyorum (AT127-B). "Neşet Ertaş aklıma geldi." (TT7-B).

\section{On İkinci Soruya Ait Bulgular ve Yorumlar}
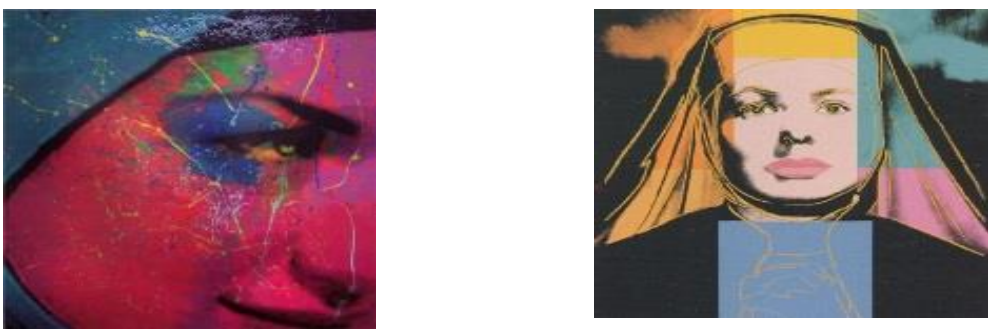

Tablo 24. Almanya'da ve Türkiye'de Yaşayan Türk Öğrencilerin Soru 12'de Batı ve Türk Sanat Eseri Tercih Dă̆ılımları

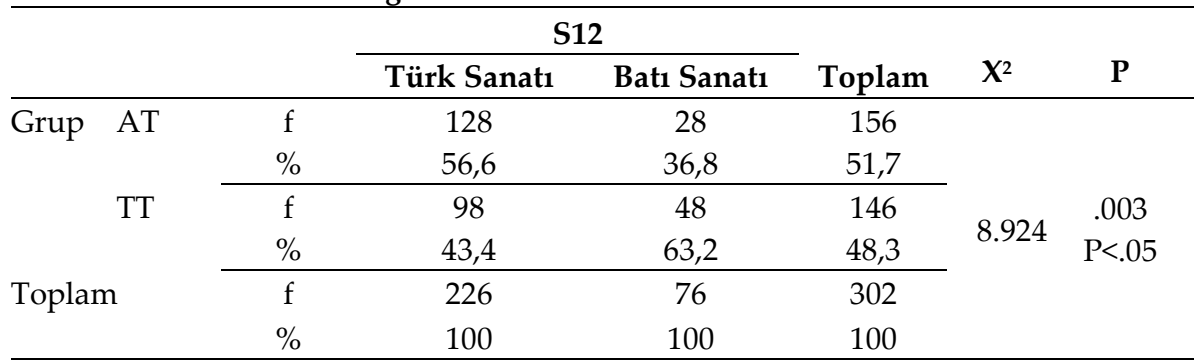

Tablo incelendiğinde Almanya'da yaşayan Türk öğrencilerle Türkiye'de yaşayan Türk öğrencilerin estetik beğenilerinde oluşan değişimde farklı bir kültürel ortamda yaşamanın etkisi olup olmadığını belirlemek 
amacıyla sunulan resimleri tercih etmeleri arasındaki fark istatistiksel olarak anlamlı bulunmuştur. $\left(X^{2}=8.924, P<.05\right)$

\section{Almanya'da ve Türkiye'de Yaşayan Türklerin Soru 12 Tercihlerini Etkileyen Temel Sebepler}

Soruyu cevaplayan tüm öğrencilerin yazdıkları bu nedenlerden yola çıkılarak Soru 12 için beş alanda tema oluşturulmuştur. Bunlar, renkler, psikolojik etkilenme, dinsel figür, fiziksel özellik, geçmiş deneyim hatırlatma ve realizm temalarıdır.

Tablo 25. Almanya ve Türkiye'de Yaşayan Türk Öğrencilerin Soru 12'de Tercih Nedenlerine Göre Dağılımları

\begin{tabular}{|c|c|c|c|c|c|c|c|c|c|c|c|}
\hline \multicolumn{12}{|c|}{$\mathrm{S} 12$} \\
\hline & & \multicolumn{2}{|c|}{ Renkler } & \multicolumn{2}{|c|}{$\begin{array}{l}\text { Psikolojik } \\
\text { Etkilenme }\end{array}$} & \multicolumn{2}{|c|}{$\begin{array}{l}\text { Dinsel Figür } \\
\text { Fiziksel Özel- } \\
\text { lik }\end{array}$} & \multicolumn{2}{|c|}{$\begin{array}{c}\text { Geçmiş } \\
\text { Deneyim } \\
\text { Hatırlatma }\end{array}$} & \multicolumn{2}{|c|}{ Realizm } \\
\hline & & $\mathrm{f}$ & $\%$ & $\mathrm{f}$ & $\%$ & $\mathrm{f}$ & $\%$ & $\mathrm{f}$ & $\%$ & $\mathrm{f}$ & $\%$ \\
\hline \multirow{2}{*}{ Grup- } & AT & 104 & 65 & 82 & 51,3 & 77 & 48,1 & 41 & 25,6 & 28 & 17,5 \\
\hline & $\mathrm{TT}$ & 90 & 60 & 63 & 42 & 85 & 56,7 & 15 & 10 & 29 & 19,3 \\
\hline
\end{tabular}

Renkler temasinda resimlerde bulunan renklerden duyulan his ya da farklı benzetimlerden dolayı edinilen yargı konusunda ortaya çıkan görüşler Almanya ve Türkiye'deki Türk öğrenciler arasında analiz edilmektedir. Bu tema ile farklı kültür şartlarında algı ve beğeninin uğradığı değişimler gözlenmek istenmiştir. Bu alanın oluşmasında dikkat çeken sunumlar şöyle sıralanmaktadır: "Eski sanatlara benziyor." (AT53-A), diyen Almanya'da bulunan Türk öğrenci bu ifadesiyle geleneksel Türk sanatı örneklerini kastetmektedir. "Rahibeye benzediği için beğendim. Ortadaki mavi leke güzel. Renkten renge geçis yok, sadece düz bir sinır var. Bu güzel." (AT92-B). Renklerin keskin ve canlı kullanılması dikkat çekmektedir. Psikolojik etkilenme temasında resimlerden Almanya ve Türkiye'deki Türk öğrencilerin kendi kültürlerine ya da içinde bulundukları kültüre göre algılama, hissetme ve yorumlama farklılıkları analiz edilmektedir. Bu alanı oluşturan öğrenci cevaplarından en belirgin olanlar şu şekilde siralanmaktadır: "Daha güzel buldum. Gül ve renkler ortada. Sicak etki yapıyor, kibar." (AT80-A). "Kadında derinlik çok iyi olmuş. Slow müzikle 
iyi gider." (TT138-A). Türkiye'de yaşayan Türk öğrencilere göre koyu tonda renklerin kullanılması hüzünlü bir duygu hissettirmiştir. Bu resim slow müzikle birlikte benzer tutulmaktadır. Dinsel figür, fiziksel özellik temasında, Almanya ve Türkiye'deki Türk öğrencilerin içinde bulundukları kendi mensup oldukları din ve dinsel inanışlar ile içinde yaşadıkları başka bir din ve dinsel inanışlar çerçevesinde resimleri değerlendirme ve beğeni oluşturma yanıtları analiz edilmektedir. Bu alanı oluşturan öğrenci yanıtlarından en belirleyici olanlar şu şekilde sıralanmıştır: "Müslümanları göstermesi, renklerin karışık olması, yine kapalı kadınların güzelliğini göstermesini beğendim." (AT9-A). Müslümanlığı ve türbanlı kadının mutlu yüz ifadesi dini içeriği sıcak, samimi yönünü temsil etmektedir. " $B$ resmini seçmem çünkü bana rahibeleri hatırlattı. A resminde bir hırs var bu duygu beni daha çok çekti." (TT28-A). İfadelerinde görüldüğü üzere B resminde konu edinilen rahibe figürü "seçmem" şeklinde kesin bir ifade ile reddedilmektedir. "Rahibe dua ediyor. Ellerin duruşu güzel." (AT157-B). Geçmiş deneyim hatırlatma temasında resimlerde yaşanan olayın günlük hayatta ya da daha öncesinde yaşanmış bir olay ya da deneyimi hatırlatıcı etkenler araştırılmaktadır. Bu alanla ilgili analiz edilen öğrenci cevapları şu şekilde sıralanmaktadır: "Resme nazaran bir şeyler ifade ediyor. Bir savaştan olan bir insan gibi. Bilmiyorum. Suriye'yi hatırlattı." (AT39-A). "Kadın beni güldürdü. Dudakları ilgi çekici. Sezen Aksu'ya benzettim." (TT140-B). B resmini tercih eden bu öğrencilerin cevaplarına göre de renklerden ve figürün fiziksel görünüşü bakımından popüler kültürle ilgili olarak da Sezen Aksu'ya benzetilmiş ve beğenilmiş olduğu anlaşılmaktadır. Realizm temasında resimlerde kullanılan figür ya da objelerin konu ve kompozisyona uygunluğu, realist görünümü ve ayrıntının kullanılmasındaki etkililik üzerine verilen yanıtlar incelenmektedir. Bu alanın oluşmasını sağlayan öğrenci görüşleri şu şekilde sıralanmaktadır: "Korkutucu, odama uygun bir resim olur. Gerçekçi." (AT34-A). Biçim ve renklerin daha baskın olduğu resimde bu cevapla realizme ait noktaların vurgulandığı da görülmektedir. 


\section{On Üçüncü Soruya Ait Bulgular ve Yorumlar}
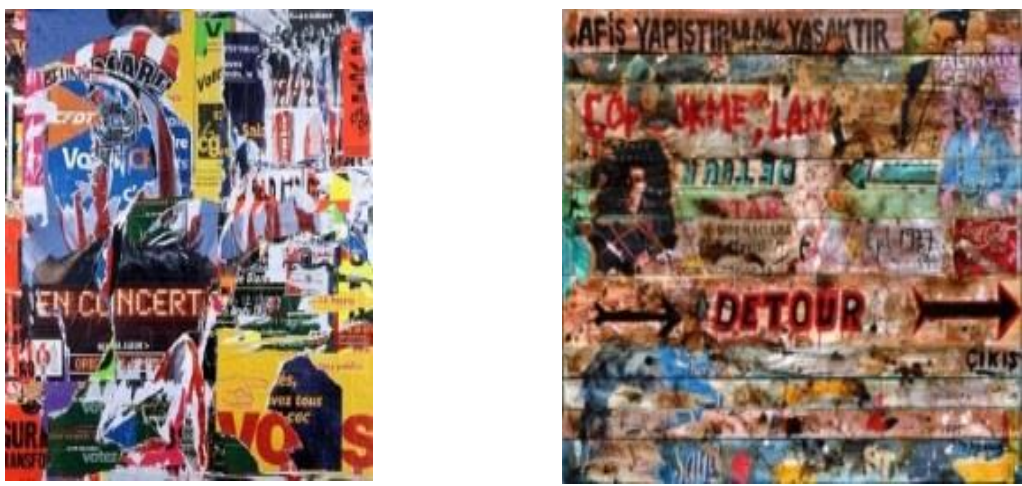

Tablo 26. Almanya'da ve Türkiye'de yaşayan Türk Öğrencilerin Soru 13'te Batı ve Türk Sanat Eseri Tercih Dă̆ılımları

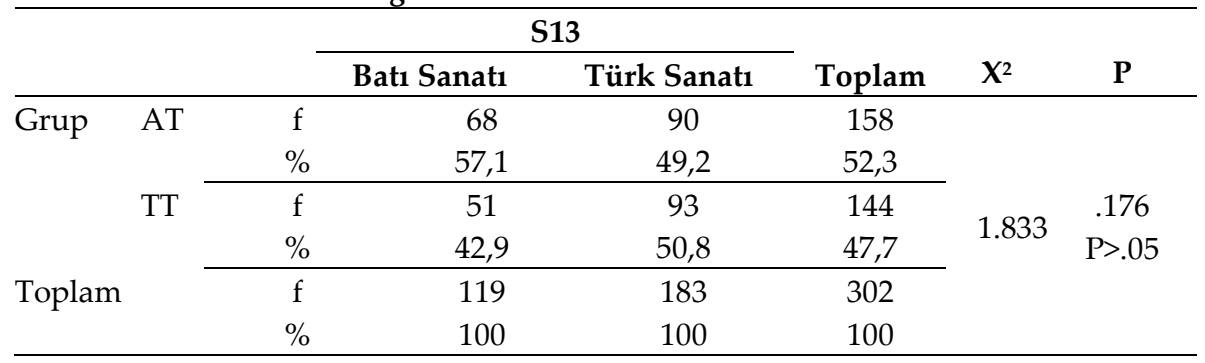

Tablo incelendiğinde Almanya'da yaşayan Türk öğrencilerle Türkiye'de yaşayan Türk öğrencilerin estetik beğenilerinde oluşan değişimde farklı bir kültürel ortamda yaşamanın etkisi olup olmadığını belirlemek amaciyla sunulan resimleri tercih etmeleri arasindaki fark istatistiksel olarak anlamlı bulunmamıştır. $\left(X^{2}=1.833, P>.05\right)$

\section{Almanya'da ve Türkiye'de Yaşayan Türklerin Soru 13 Tercihlerini Etkileyen Temel Sebepler}

Soruyu cevaplayan tüm öğrencilerin yazdıkları bu nedenlerden yola çıkarak Soru 13 için dört alanda tema oluşturulmuştur. Bunlar, renkler, 
geçmiş deneyim, psikolojik his, dil ve kültürel özellik, teknik özellik temalarıdır.

Tablo 27. Almanya ve Türkiye'de Yaşayan Türk Öğrencilerin Soru 13'te Tercih Nedenlerine Göre Dağılımları

\begin{tabular}{|c|c|c|c|c|c|c|c|c|c|}
\hline \multicolumn{10}{|c|}{ S13 } \\
\hline & & \multirow{2}{*}{\multicolumn{2}{|c|}{ Renkler }} & \multirow{2}{*}{\multicolumn{2}{|c|}{$\begin{array}{c}\text { Geçmiş Deneyim } \\
\text { Hatırlatma } \\
\text { Psikolojik His }\end{array}$}} & \multirow{2}{*}{\multicolumn{2}{|c|}{$\begin{array}{c}\text { Dil ve } \\
\text { Kültürel } \\
\text { Özellik } \\
\end{array}$}} & \multirow{2}{*}{\multicolumn{2}{|c|}{ Teknik Özellik }} \\
\hline & & & & & & & & & \\
\hline & & $\mathrm{f}$ & $\%$ & $\mathrm{f}$ & $\%$ & $\mathrm{f}$ & $\%$ & $\mathrm{f}$ & $\%$ \\
\hline \multirow{2}{*}{ Grup } & AT & 88 & 55 & 71 & 44,4 & 60 & 37,5 & 71 & 44,4 \\
\hline & TT & 57 & 38 & 63 & 42 & 71 & 47,3 & 64 & 42,7 \\
\hline
\end{tabular}

Renkler temasinda resimlerde bulunan renklerden duyulan his ya da farklı benzetimlerden dolayı edinilen yargı konusunda ortaya çıkan görüşler Almanya ve Türkiye'deki Türk öğrenciler arasında analiz edilmektedir. Bu tema ile farklı kültür şartlarında alg1 ve beğeninin uğradığı değişimler ya da özlemler gözlenmek istenmiştir. Bu alanın oluşmasında dikkat çeken sunumlar şöyle sıralanmaktadır: "Kaos, karışık, sıcak renkler." (AT35-B). "Renklerin karışımı çok güzel. Afişin yasak olması ve farklı tonların olması güzel." (TT149-B). Türkiye ve Almanya'daki Türk öğrencilere göre A resmindeki renkler daha açık ve huzurlu; B resmindeki renkler canlı, karmaşık ve farklı tonlardadır. Bu durumun B resmini taraftarların olduğu coşkulu bir stadyum görünümünü hatırlatmasını A resminin ise huzurlu bir ortamı hatırlatmasını sağladığı düşünülmektedir. Geçmiş deneyim, psikolojik his temasında resimlerde yaşanan olayın günlük hayatta ya da daha öncesinde yaşanmış bir olay ya da deneyimi hatırlatıcı etkenler araştırılmaktadır. Duncum (2004, s.252), eğer televizyon programlarını izlerken sesini kapatırsak diyaloğun olayı anlamada ne kadar önemli olduğunu anlayacağımızı; eğer metni kesersek de imajların güzel olmasına rağmen anlamlandırılmasının zor olabileceğini ifade etmiş ve sembollerin ve dilin anlamsal gücünü vurgulamaya çalışmıştır. Her bir kültürel alandaki alg1, görselin iletişimsel biçimini gerektirir. Bu doğrultuda kültürel faktörlerin, kelimelerin veya yazılı metinlerin ve popüler görüntülerin bu yaşanmışlıkları hatırlatmadaki etkisi de cevapların analiz edilmesiyle belirlenmeye çalışılmaktadır. Bu alanla ilgili analiz edilen öğrenci cevapları şu şekilde sıralanmaktadır: “Türkiye'yi hatırla- 
tıyor. Türkiye'nin sokakları, Türkiye'nin gerçek araçları." (AT127-B). Almanya'da yaşayan Türk öğrenciler B resmindeki görüntüyle Türkiye'nin sokaklarını hatırladıklarını ifade etmişlerdir. Türkiye'de de Almanya'da olduğu gibi duvar yazısı ya da resimleri örnekleri son dönemlerde görülmeye başlanmıştır. "Bana Getto'yu hatırlatıyor." (AT150-B). Dil ve kültürel özellik temasında öğrencilerin kültür bağlamında şekil ve renklerden daha çok dili algılama yetileri ve farklılıkları anlamak, farklı dil ve kültürlere olan ilgilerini ortaya çıkarmak için verilen yanıtlar analiz edilmiştir. Bu alanı oluşturan belirgin örnekler şu şekilde sunulmaktadır: "Diğer resmi anlamadığım için, bu resimdeki dilleri anlıyorum." (AT126-B). "Türkiye." (AT91-B). Dubuffet (2010, s.29), herkesin kendine ait dili diğerlerine göre daha kültürel konuştuğunu, kültürel konuşmanın ise kültürel düşünmeye bağlı olduğunu ifade etmektedir. Ona göre düşünceyi dil yapar ve kültür, bir bilgilenim malzemesi olmanın da ötesinde bir düşünüş, kendini ifade ediş, bir görüş, duyuş ve davranış tarzıdır. "Amerika falan var." (TT148-A). A resmini tercih eden Türk öğrenciler ise B resminde Türkçe ifadeleri fark etmiş yani bu resmin Türk sanatına ait bir eser olduğunu, A resminin de Batı sanatını yansıtan bir resim olduğunu bilerek tercihini yapmıştır. "Türk kültürüne uyumlu olduğu için, Türkçe yazılar olduğu için, bildiğim ve uygulamaya alışkın olduğum teknik için beğendim." (TT30-B). Teknik özellik temasında öğrencilerin resmin yapılış araç ve yöntemlerini göz önünde bulundurduğu değerlendirme cevapları bulunmaktadır. Bu alanı oluşturan en belirgin yanıtlar şöyle sıralanmaktadır: "Resmin kaynă̆ı ve teması benim ilgimi çekiyor." (AT112-B). "Sportif bir mesajı var. Rengi ve karmaşıklı̆̆ı iyi. Simgeler güzel." (TT139-A).

\section{On Dördüncü Soruya Ait Bulgular ve Yorumlar}
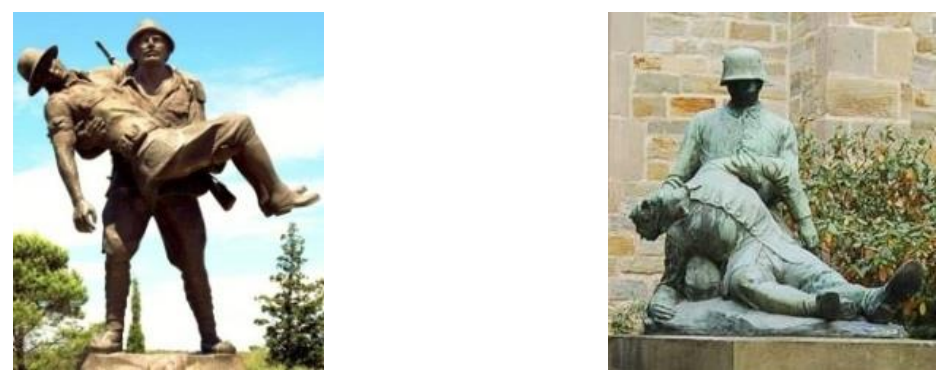
Tablo 28. Almanya'da ve Türkiye'de Yaşayan Türk Öğrencilerin Soru 14'te Batı ve Türk Sanat Eseri Tercih Dă̆ılımları

\begin{tabular}{|c|c|c|c|c|c|c|c|}
\hline & & & \multicolumn{2}{|c|}{$\mathrm{S} 14$} & \multirow[b]{2}{*}{ Toplam } & \multirow[b]{2}{*}{$X^{2}$} & \multirow[b]{2}{*}{$\mathbf{P}$} \\
\hline & & & Türk Sanatı & Batı Sanatı & & & \\
\hline \multirow[t]{4}{*}{ Grup } & AT & $\mathrm{f}$ & 142 & 16 & 158 & \multirow{6}{*}{6.579} & \multirow{6}{*}{$\begin{array}{c}.010 \\
\mathrm{P}<.05\end{array}$} \\
\hline & & $\%$ & 50,4 & 80 & 52,3 & & \\
\hline & TT & $\mathrm{f}$ & 140 & 4 & 144 & & \\
\hline & & $\%$ & 49,6 & 20 & 47,7 & & \\
\hline \multirow{2}{*}{\multicolumn{2}{|c|}{ Toplam }} & $\mathrm{f}$ & 282 & 20 & 302 & & \\
\hline & & $\%$ & 100 & 100 & 100 & & \\
\hline
\end{tabular}

Tablo incelendiğinde Almanya'da yaşayan Türk öğrencilerle Türkiye'de yaşayan Türk öğrencilerin estetik beğenilerinde oluşan değişimde farklı bir kültürel ortamda yaşamanın etkisi olup olmadığını belirlemek amaciyla sunulan resimleri tercih etmeleri arasindaki fark istatistiksel olarak anlamlı bulunmuştur. $\left(X^{2}=6.579, P<.05\right)$

\section{Almanya'da ve Türkiye'de Yaşayan Türklerin Soru 14 Tercihlerini Etkileyen Temel Sebepler}

Soruyu cevaplayan tüm öğrencilerin yazdıkları bu nedenlerden yola çıarak Soru 14 için dört alanda tema oluşturulmuştur. Bunlar, duygusal yorumlama ve askerin duruşu, savaş ve Türk algısı ile Çanakkale; renkler ve net olma; geçmiş deneyim hatırlatma temalarıdır.

Tablo 29. Almanya ve Türkiye'de Yaşayan Türk Öğrencilerin Soru 14'te Tercih Nedenlerine Göre Dă̆ılımları

\begin{tabular}{|c|c|c|c|c|c|c|c|c|c|}
\hline \multicolumn{10}{|c|}{ S14 } \\
\hline & & \multicolumn{2}{|c|}{$\begin{array}{l}\text { Duygusal Yo- } \\
\text { rumlama, Aske- } \\
\text { rin Duruşu }\end{array}$} & \multicolumn{2}{|c|}{$\begin{array}{l}\text { Savaş ve } \\
\text { Türk Algisı } \\
\text { Çanakkale }\end{array}$} & \multicolumn{2}{|c|}{$\begin{array}{l}\text { Renkler ve } \\
\text { Net Olma }\end{array}$} & \multicolumn{2}{|c|}{$\begin{array}{c}\text { Geçmiş Dene- } \\
\text { yim } \\
\text { Hatırlatma }\end{array}$} \\
\hline & & $\mathrm{f}$ & $\%$ & $\mathrm{f}$ & $\%$ & $f$ & $\%$ & $f$ & $\%$ \\
\hline \multirow{2}{*}{ Grup } & AT & 132 & 82,5 & 55 & 34,4 & 51 & 31,9 & 47 & 29,4 \\
\hline & TT & 120 & 80 & 84 & 56 & 20 & 13,3 & 47 & 31,3 \\
\hline
\end{tabular}

Duygusal yorumlama ve askerin duruşu temasında resimler karşısında alınan tavır, askerlerin duruşundan kaynaklanan yardımseverlik, güç, acı ya da savaş gibi düşüncelerin anlaşılmasını sağlayan cümleler analiz 
edilmektedir. Bu alanın oluşmasını sağlayan öğrenci yanıtlarından en belirgin olanlar şöyle siralanmaktadır: A resminde adam yaralıya yardım edecekmiş gibi görünüyor. B resmi zorbaca göründü. A resminde çok ayrıntı var, bu durum titiz çalışıldığını kanıtlıyor." (AT160-A). Almanya' da yaşayan Türk öğrencilerden bazıları cesaret gösteren A resmindeki canlılığı, gerçekliği ve yardımseverliğin yansıtımını beğenmişlerdir. "Adam meslektaşını ölü olmasına rağmen bırakmadığı için beğendim. Çünkü yaşayanın acısı hissediliyor ve görülüyor. Buna rağmen devam ediyor. Çünkü durum çok özgüvenli." (AT69-A). "Daha güçlü etkisi var. Şerefli, memleketi anımsatan, vakarl,, gösterişli." (AT35-A). A resminde figürün dik duruşu kendine güvenen, şerefli, vakarlı ve gösterişli olarak anlamlandırılmıştır. Memleketi anımsatan, kendi vatanına yakın olma ifadesi askerin duruşu, kıyafetinden doğabileceği gibi çevredeki görünümden, yeşil ağaçlardan ve gökyüzünden de bu his edinilmiş olabilir. Türkiye'de yaşayan Türk öğrencilerden bazıları A resminin yardımseverlik mesajı verdiğini ifade etmiştir. "Türk askerini gördüm. Asker yardımcı oluyor. Anlamı çok büyük, hümanizmi yansitıyor." (TT25-A). "Mehmetçik, şehit askeri taşırken bile dimdik ayakta." (TT3-A). Savaş ve Türk algısı ile Çanakkale temasında vatanın tarihsel geçmiş sürecinde yaşanmış ve öğrenilmiş olayların bıraktığı izler yoluyla ve kültürel değişimin etkisiyle oluşabilecek algı ve beğenilerdeki değişim analiz edilmektedir. Bu alanın oluşmasını sağlayan öğrenci cevaplarından en belirgin olanları şu şekilde sıralanmaktadır: "Çanakkale olduğu için ve Çanakkale'yi çok sevdiğim için. Diğer resim hoşuma gitmedi. Askerleri sevdiğim için bu resmi beğendim." (AT126-A). "Çok sıkı bir arkadaşlık var. Çanakkale savaşını hatırlatıyor, vatancıyım." (AT86-A). "Vatancıyım." ifadesi milliyetçilik anlamında güçlü bir ifadedir. Renkler ve net olma temasinda heykellerin bulundukları mekânda çekilmiş fotoğrafları üzerinden değerlendirme yapılmaktadır. Bu alanı oluşturan Almanya ve Türkiye'deki Türk öğrencilerin cevaplarından en belirgin olanlar şu şekilde sıralanmaktadır: "Güzel arka plan, açık renkler kahramanca resim." (AT158A). "Adam yaralıyı kollarında taşıyor. Asker saygıyı gösteriyor. Heykelin rengi güzel." (AT97-A). Geçmiş deneyim hatırlatma temasında öğrencilerin resimler üzerinde kendi yaşanmışlıklarını bulmaları yönündeki beğenileri incelenmektedir. Bu tema için verilen cevapların en belirgin örnekleri şunlardır: "Derste bu konuyu görmüş̧ük. Daha güzel bir sahne, kahramanca." (AT34-A). "Çünkü bu olay gerçek. Bu heykeli Çanakkale'de gördüm. Hüzünlü 
bir hikâye." (TT135-A). "Çanakkale geçilmez. Burada küçüklük fotoğrafım var." (TT39-A). Aile içinde olan bazı deneyimlerin yanında okulda ve başka çevrelerde de öğrencilerin edindikleri deneyimlerin bu soru için beğeni oluşturduğu görülmektedir.

\section{On Beşinci Soruya Ait Bulgular ve Yorumlar}
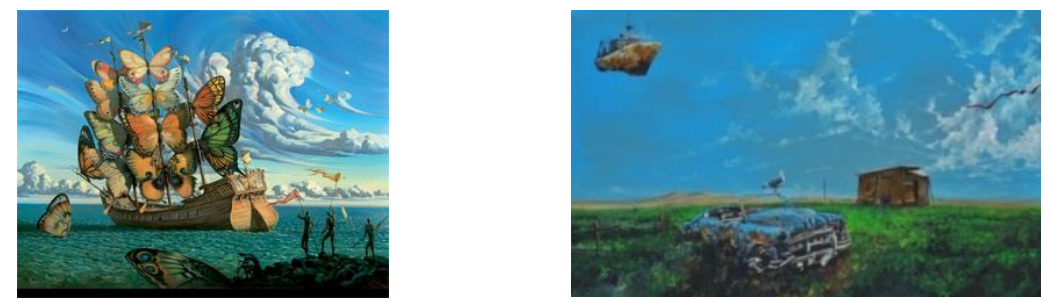

Tablo 30. Almanya'da ve Türkiye'de Yaşayan Türk Öğrencilerin Soru 15'te Batı ve Türk Sanat Eseri Tercih Dă̆ılımları

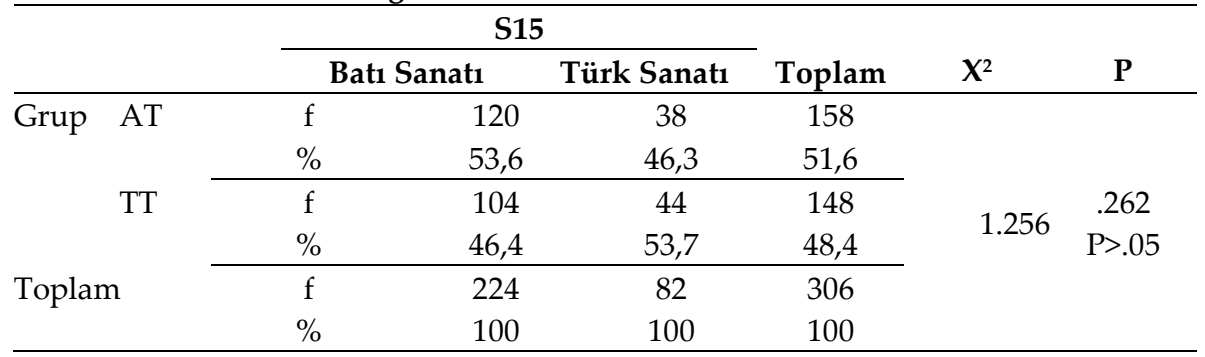

Tablo 30 incelendiğinde Almanya'da yaşayan Türk öğrencilerle Türkiye'de yaşayan Türk öğrencilerin estetik beğenilerinde oluşan değişimde farklı bir kültürel ortamda yaşamanın etkisi olup olmadığını belirlemek amaciyla sunulan resimleri tercih etmeleri arasındaki fark istatistiksel olarak anlamlı bulunmamıştır. $\left(X^{2}=1.256, P>.05\right)$

\section{Almanya'da ve Türkiye'de Yaşayan Türklerin Soru 15 Tercihlerini Etkileyen Temel Sebepler}

Soruyu cevaplayan tüm öğrencilerin yazdıkları bu nedenlerden yola çıkarak Soru 15 için beş alanda tema oluşturulmuştur. Bunlar, sürrealizm ve hayal gücü, renklerin görünüşü; neşe, özgürlük, üzüntü gibi duygula- 
rın yorumlanması; objelerin etkisi; olgu ya da olay hatırlatması, benzetim yapma temalarıdır.

Tablo 31. Almanya'da ve Türkiye'de Yaşayan Türk Öğrencilerin Soru 15'te Batı ve Türk Sanat Eseri Tercih Dağılımları

\begin{tabular}{|c|c|c|c|c|c|c|c|c|c|c|c|}
\hline \multicolumn{12}{|c|}{ S15 } \\
\hline & & \multicolumn{2}{|c|}{$\begin{array}{l}\text { Sürrealizm } \\
\text { Hayal Gücü }\end{array}$} & \multicolumn{2}{|c|}{$\begin{array}{l}\text { Renklerin } \\
\text { Görünüşü }\end{array}$} & \multicolumn{2}{|c|}{$\begin{array}{c}\text { Neşe, Özgür- } \\
\text { lük, Üzüntü } \\
\text { Gibi Duygu- } \\
\text { ların Yorum- } \\
\text { lanması }\end{array}$} & \multicolumn{2}{|c|}{$\begin{array}{l}\text { Objelerin } \\
\text { Etkisi }\end{array}$} & \multicolumn{2}{|c|}{$\begin{array}{c}\text { Olgu ya da } \\
\text { Olay Hatır- } \\
\text { latması } \\
\text { Benzetim } \\
\text { Yapma } \\
\end{array}$} \\
\hline & & $\mathrm{f}$ & $\%$ & $\mathrm{f}$ & $\%$ & $\mathrm{f}$ & $\%$ & $\mathrm{f}$ & $\%$ & $f$ & $\%$ \\
\hline \multirow{2}{*}{ Grup- } & AT & 57 & 35,6 & 66 & 41,3 & 81 & 50,6 & 106 & 66,3 & 53 & 33,1 \\
\hline & TT & 46 & 30,7 & 52 & 34,7 & 47 & 31,3 & 106 & 70,7 & 18 & 12 \\
\hline
\end{tabular}

Sürrealizm ve hayal gücü temasında resimde görülen ya da hissedilen obje, figür, biçim gibi resmi oluşturan elemanların hayal gücü ve sürrealist yapıda değerlendirilen cümleler analiz edilmektedir. Bu alanı oluşturan en belirgin öğrenci cevapları şu şekilde sıralanmaktadır: "Gökyüzündeki bir sarayı hatılatıyor, hayal ülkesine ruhların seyahati." (AT122-B). "Sıra dışı." (AT105-A). "Tasarım ilginç, hayalperest." (TT84-A). Almanya'da yaşayan Türk öğrenciler ve Türkiye'de yaşayan Türk öğrenciler bu eserlerde gerçek dışı kurgulanmış durumları beğenmektedir. Renklerin görünüşü temasında resimlerde bulunan renklerden duyulan his ya da farklı benzetimlerden dolayı edinilen yargı konusunda ortaya çıan görüşler Almanya ve Türkiye'deki Türk öğrenciler arasında analiz edilmektedir. $\mathrm{Bu}$ alanın oluşmasında dikkat çeken sunumlar şöyle sıralanmaktadır: "Resim çok açık, renkler de açık insanı sevindiren bir atmosfer var. Gemide olan kelebekler, gemiyi uçuracak gibi duruyor. Bulutlar da rüzgârın nereye doğru üflediğini gösteriyor. Bu durum uză̆ı anlatıyor." (AT31-A). "Çim olan arazi insana huzur veriyor. Oyun alanı gibi. İnsanın içi enerji doluyor." (TT150-B). B resmini tercih eden Almanya ve Türkiye'deki Türk öğrenciler için renkler güzel görünmektedir. Bu alanı oluşturan en belirgin öğrenci cevapları şu şekilde sıralanmıştır: Uzak yeşil ve boş tarla daha özgür duruyor. Mavi araba ve çadır eğlenmek için bir gezi yapılmış gibi görünüyor. Havadaki örtü rüzgâr anlamina geliyor. Daha özgür, problem yok." (AT70-B). Resimde uçan örtünün etkisiyle rüzgârın estiği yorumunu yapan öğrenci, resimde 
daha çok özgürlük duygusunu hissetmiş ve bu nedenle beğenmiştir. Bu alanı oluşturan öğrenci cevaplarından en belirgin olanlar şu şekilde sıralanmıştır: "Kelebekler geminin hava ile hareketini gösteriyor. Yani bu resim insanı yeryüzünde ne olduğu hakkında düşündürüyor." (AT16-A). Olgu ya da olay hatırlatması, benzetim yapma temasında resimlerde görülen kompozisyon ya da olayların öncesinde yaşanmış bir olay hatırlatması ya da eskiden hatırlanan bir duruma benzetme nedeniyle sunulan beğenme ifadeleri analiz edilmektedir. Bu alanı oluşturan cevaplardan en belirgin olanları şu şekilde sıralanmıştır. "One Piece gibi. Korsan gemisi hakkında ve su hakkında yapılmıs bir resim." (AT19-A). "Jack Sparrow, kelebek ve gemi." (TT15- $A$ ). Türkiye'deki Türk öğrenciler popüler kültürün parçaları olan günümüzde gösterimde olan filmlerle bağlantı kurmaktadırlar.

\section{Sonuç, Tartışma ve Öneriler}

$\mathrm{Bu}$ araştırmada farklı kültürlerde yaşayan 12-17 yaş grubundaki Türk öğrencilerin estetik tercihlerinde kültürün etkisinin ve estetik beğeniyi etkileyen faktörlerin neler olduğuna dair iki problem belirlenmiştir. Araştırmada "farklı kültürlerde yaşayan 12-17 yaş grubundaki Türk öğrencilerin estetik tercihlerinde kültürün etkisi var mıdır?" sorusuna yanıt bulmak için Batı sanat eseri ve Türk sanat eseri arasındaki tercih oranları değerlendirilmiştir. Bu değerlendirme iki grupta bulunan öğrencilerin tercih durumların gösteren grafiklerle birlikte aşağıda sunulmuştur.

1.soru, renk ve formların kültürel sayılabilecek bazı şekillerin belirgin olduğu resimleri içermektedir. Bu soru için ele alınan iki grup öğrencinin dağılımlarında birbirine yakınlık olduğu anlaşılmaktadır. 2.soru, Türk ve Batı kültüründen izler taşıyan natürmort konulu resimler içermektedir. Bu soruda Almanya'da ve Türkiye'de yaşayan Türk öğrencilerin çoğunluğunun Batı sanatına ait eseri daha çok beğendiği görülmektedir. 3.soru, mekân-kültür ilişkisinden yola çıkılarak yaşanılan çevrenin kültüre göre düzenlenmesi, yansıtılması ve algılanmasına yönelik eğilimler saptanmıştır. Ankette bu soruyu yanıtlayan öğrencilerden çoğu Batı sanat eserini seçmiştir. 4.soru, peyzajla birlikte figürlerin kültürel kıyafetlerinin de vurgulandığı resimleri içermektedir. Genel olarak bakıldığında Almanya'da yaşayan Türk öğrencilerle Türkiye'de yaşayan Türk öğren- 
cilerin çoğunluğu Türk sanat eserini tercih etmiştir. 5.soruda, kübizm akımının Türk sanatı ve Batı sanatındaki belirgin örnekleri olan resimler seçilmiştir. Almanya ve Türkiye'de yaşayan Türk öğrencilerin çoğu Türk sanat eserini beğenmiştir. Bu öğrencilerden bazıları figürün kıyafetindeki desenleri ya da fondaki motifleri Türk kültürü ile ilişkilendirerek bu tercihi yapmıştır. Portre konulu olan 6.sorudaki resimler iki ayrı kadın portresini ele almıştır. Kültürel özellikleri sergileyen bu resimlerde figürlerin Batı kültürüne ait olan şapka, yelpaze, fular gibi objelere karşıllık Türk kültürünü yansıtan geleneksel bir başlık görülmektedir. Araştırmaya katılan öğrencilerin Batı ve Türk sanat eserini tercih etme sayıları birbirine yakın oranlarda olmuştur. 7.soru, Almanya'da sanat dersi müfredat programında incelenen bir eser ile ona kompozisyon, renk ve konu bakımından eş değer olabilecek Türk sanatından benzer bir eseri içermektedir. Türk öğrencilerin de büyük çoğunluğu Batı sanat eserini tercih etmiştir.

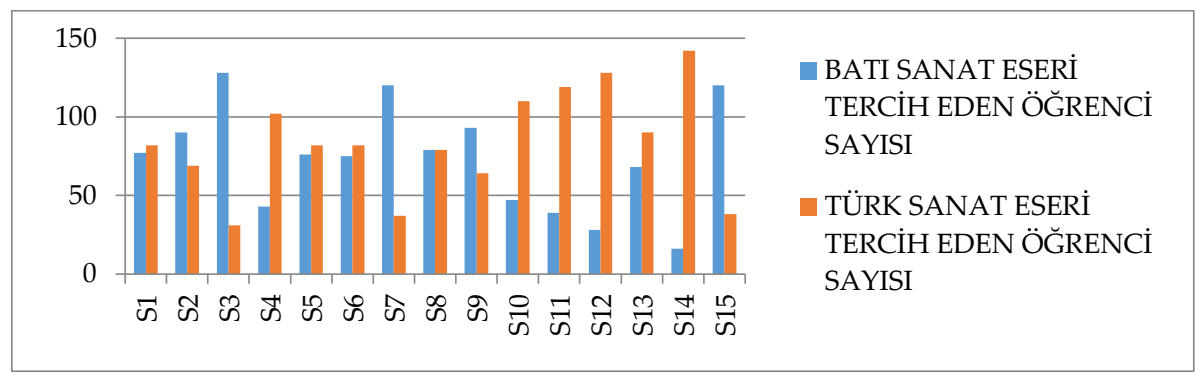

Şekil 1. Almanya'daki Türk Öğrencilerin Sanat Eseri Tercih Durumu

8.soruda, Türkiye'de yaşayan Türk öğrencilerin çoğunluğu da Türk sanat eserini tercih etmiştir. Türk sanat eserinde kadın figürünün başörtüsü, çocuklarını arkadan desteklemesi, çocukların ellerindeki ekmek parçası, özellikle Türk öğrenciler tarafından geleneksel köy yaşamı, güçlü Türk kadını ve emek duygusu şeklinde algılanmıştır. Almanya'da yaşayan Türk öğrencilerin bu duygularda daha hassas oldukları gözlenmiştir. 9.soru, Batı ve Türk kültüründe çalışan işçileri konu edinen eserler içermektedir. Türkiye'de yaşayan Türk öğrencilerin çoğunluğu Türk sanat eserini tercih etmiştir. Türk öğrenciler resimde bulunan figürlerin kollarındaki kaslı görünümü "Türk Gücü" olarak yorumlamıştır. 
Ayrıca maden işçilerini Türkiye'deki maden işçileriyle bağdaştırarak bu eseri daha çok beğenmişlerdir. Almanya'da yaşayan Türk öğrencilerin çoğunluğu da Batı sanat eserini tercih etmiştir. 10.soruda, kültür konusunda dinin etkisini ve dine eğilimi anlamaya yönelik olan bu sorudaki resimlerde cami ve şato ya da katedral objelerinden yola çıkılmıştır. Almanya ve Türkiye'de yaşayan Türk öğrenciler ise ağırlıkla Türk sanat eserini beğenmiştir. Almanya'da bulunan Türk öğrencilerin cami figüründen dolayı beğeni göstermeleri İstanbul ve Türkiye'de bulunan camilere duyulan özleme ve dini duygulara dayanmaktadır. 11.soruda birbirine renk ve biçim bakımından benzer olan Türk ve Batı sanatından eserler görülmektedir. Almanya ve Türkiye'de yaşayan Türk öğrencilerin büyük çoğunluğu Türk sanat eserini beğenmiştir. Bu beğenide resimdeki figürün Aşık Veysel'e benzetimi ve enstrümanın geleneksel Türk çalgısı olarak algılanması etkin görülmektedir. 12.soru, dinin figüratif içerikle ele alındığı Pop art örneği olan eserlere sahiptir. Öğrenciler figürlerin dinsel özellikler içeren ayrıntılarını fark edip değerlendirme yapmışlardır. Almanya ve Türkiye'de bulunan Türk öğrencilerin de çoğunlukla Türk sanat eserini tercih ettiği anlaşılmaktadır. Batı sanat eserinde bulunan rahibe figüründen hoşlanmama ve ait oldukları dinin dışında bir özellik yansıtması nedeniyle Türk sanat eseri beğenilmiştir. 13.soruda kültür içerisinde dil faktörünün beğenide etkililiği ölçülebilir. Resimler ait olduğu kültürün dilinden ifadeler ve o kültürle özdeşleşmiş ayrıntılar içermektedir. Almanya ve Türkiye'de bulunan Türk öğrencilerin çoğunluğu da Türk sanatına ait eseri beğenmişlerdir. 14.soruda öğrencilere, Türk ve Alman tarihinde önemli olan savaş, kahramanlık ve milli duyguları uyandıran heykel örnekleri sunulmuştur. Türk sanat eseri olan ve Türk kahramanlığını anlatan heykeli ise Almanya ve Türkiye'de yaşayan Türk öğrencilerin neredeyse tamamı tercih etmiştir. Özellikle Almanya'da bulunan Türk öğrencilerin bu eseri tercih etmelerindeki başlıca etmen kendi tarihlerinin kahramanlık hissettiren gösterişi ve vatan özlemidir. 15.soru, öğrencilerde soyut düşünme ve hayal gücünden yola çıkılarak algı ve ayırt etmeyi ölçme amaçlı resimler içermektedir. Almanya ve Türkiye'de yaşayan Türk öğrencilerin büyük çoğunluğu Batı sanat eserini tercih etmiştir. 


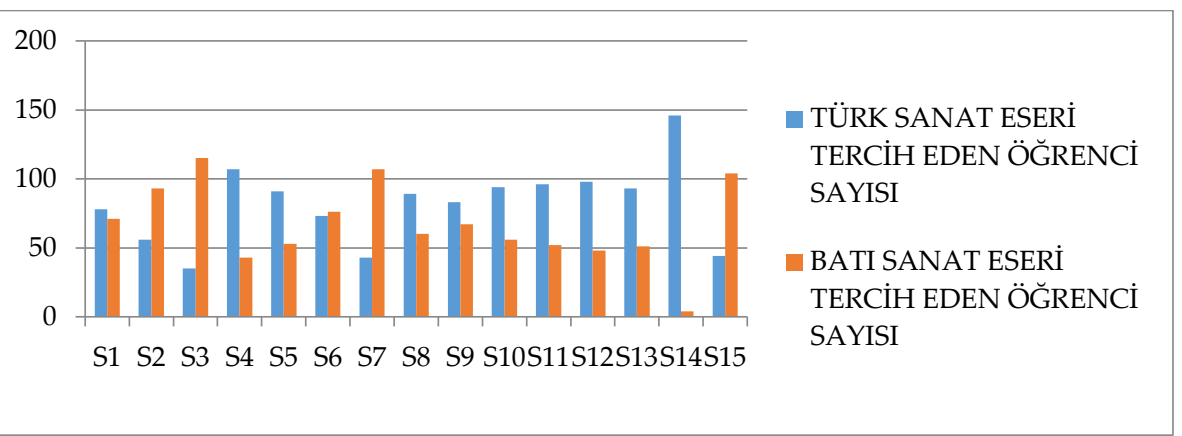

\section{Şekil 2. Türkiye'deki Türk Öğrencilerin Sanat Eseri Tercih Durumu}

Araştırmanın ikinci problemini oluşturan, "Estetik beğeniyi etkileyen faktörler nelerdir?" sorusuna yant bulmak için anket formundan toplanan verilere göre Almanya'da yaşayan Türk ve Türkiye'de yaşayan Türk öğrencilerin Batı sanat eseri ve Türk sanat eseri arasında tercih yaparken sundukları gerekçeler değerlendirilmiştir.

Araştırmada elde edilen betimsel bulgulara göre, araştırmaya katılan öğrencilerin sosyal birikimler çatısı altında kişisel eğilimlerinin, geçmiş deneyimlerinin beğeni ve tercihlerinde etkili olduğu anlaşılmıştır. Ankette Soru 1'de şekilleri Türk öğrencilerin ise daha çok çocukluk dönemlerinde sahip oldukları oyuncakları ya da mekân olarak Berlin Duvarı'nı hatırladıkları anlaşılmaktadır. Verilen cevaplardan kültür değişiminde algısal farklılığın yaşanabileceği anlaşılmaktadır. Almanya'da yaşayan Türk öğrenci "Şekiller bana Noel A ğacını hatırlattı." (AT87-B) derken Türkiye'de yaşayan Türk öğrenci ise "Yuvarlaklar bana misketi hatırlattı." (TT122-A), ifadelerini kullanmaları bu duruma örnektir. Ayrıca Türkiye'de aile büyükleri, arkadaş ya da yakın çevre ile yapılan yıllık tatiller, öğrenciler için sonrasında hatırlanan bir deneyim olmuştur. Soru 2'de bulunan resimlerin Almanya'da yaşayan Türk öğrenciler için Ramazan ayını hatırlatıp fakirlere yardım hissini uyandırıyor olması dikkat çekicidir. Cezve ve çaydanlığın Türkiye'yi ve kahveyi hatırlatması, bir diğer öğrencinin "Türk Çayı" vurgusunu özellikle yapması vatana duyulan özlemden dolayı algının bu yöne doğru ilerlediğini göstermektedir. Türkiye'de yaşayan Türk öğrenciler ise beğenilerini resmin Osmanlı'yı hatırlatmasına, resimdeki bakış açısına, meyvelerin belirgin oluşuna ve avizelerin kullanışına bağlamaktadır. 
Almanya'da yaşayan Türk öğrencilerindeki bir diğer kültürel vurgulama, Atatürk, Çanakkale Savaşı, bayrak gibi milli sembolleri algılamadaki güçlü tutum gibi Türkiye'de yaşayan Türk öğrencilerinde de bu durum fark edilebilir. Ancak bazı gurbetçi öğrencilerde bu algının zayıf olduğu da anlaşılmaktadır. Bu eserin tarihi yansıttığını ifade eden Türk öğrencilerin milliyetçilik duygularının baskın olduğu anlaşılmaktadır. Burada yine Türkiye'ye duyulan özlemden söz edilebilir. Almanya'daki ve Türkiye'deki Türk öğrenciler için bu eser kahramanlığın simgesidir ve Türk askerinin yardımseverliğini vurgulamaktadır. Tarihsel değerlerin beğenide etkililiğinin vurgulanacağı bir diğer nokta ise devlet liderleri ya da tarihsel kahraman kavramlarıdır. Devlet kurucuları, bir milletin var oluşunda önemli rol oynayan devlet adamları ait olduğu kültürle birlikte anılmaktadır. Dolayısıyla o toplumun kültürüyle özdeşleşen belli isimler kültürü yansıtan kavramlar olmaktadır. Türk milleti için bu yansıtım Atatürk kavramıdır. Ankette uygulanan 7. soruda Batı sanat eserinde yer alan figür üzerinden yapılan yorumlar, resimdeki sıradan bir figürün algılanmasındaki farklılıkları göstermektedir. Türk öğrenciler zirvede durması nedeniyle bu figürü Atatürk olarak yorumlamaktadır.

Sadece obje değil aynı zamanda olayların yorumlanması da kültürel değerlendirme olarak karşımıza çıkmaktadır. Örneğin 8. soruda Türk sanat eserinde yer alan figürlerin giysilerinin yöresel olduğunun ifade edildiği görülmektedir. Buradaki kadınlara, Anadolu kadını, gelenekAnadolu, geleneksellik şeklinde anlamlar yüklenmiştir. Aynı figürlerin ellerinde ekmek parçası tutan çocukların olması burada kırsal kesimde yaşayan Türk insanının olduğu yorumunun yapılmasını sağlamıştır. 9.sorudaki işçilerin kıyafetleri ve güçlü duruşları da bu esere Türk kimliği kazandırmıştır. Türk gücü olarak nitelenen figürde belirgin olan kol kasları öğrenciler için ilgi çekici bir ayrıntı olmuştur. Türk kültürü ya da Batı kültürünün hepsinde var olan bu imgeler olaylarla ilişkilendirildiğinde insanın ait olduğu kültürde karşılığını bulmaktadır. Yukarıda bahsedilen kıyafetler, şapkalar, yelpazeler, enstrümanlar, motifler, danteller farklı iki kültürde karşılığı olan imgelerdir. İmgelere anlam kazandıran sosyal olaylar, gelenekler, ahlaki değerler ve dinin de etkisinin olduğu verilen yanıtlardan anlaşılmaktadır.

Ahlaki değerler, gelenekler ve özellikle din konusu beğenide baskın olan konular arasındadır. Almanya'da yaşayan Türklerde gelenek kav- 
ramı daha özel ve önemli olabildiği kadar yerine getirilmede en zorlanılan şey de olabilir. Bu anlamda evlilik törenlerinde, dini bayramlarda ya da günlük hayattaki bazı kurallarda geleneklere bağlı olmak burada olan Türkler için daha hassas bir durumdur. Bu kuralların tartışmasız kabulünün olduğu tek alan dindir. Dinin kültürü oluşturan bir unsur olduğu düşünüldüğ̈̈nde toplumsal yapıyı oluşturan en temel olgunun da din olduğunu anlamak zor olmayacaktır. Almanya'da yaşayan Türkler için bir camiyi, minareyi görmek, ezan sesi duymak gibi dini içerikli günlük olaylar yaşanan çevre dolayısıyla sıradan bir durum değildir. Yahya Kemal'in (1938, s. 5) dediği gibi; "Ezansiz ve minaresiz semtlerde büyüyen, oynayan Türk çocuklarn milliyetlerinden tam bir derecede nasip alabiliyorlar mı? O semtlerde ki, minare görülmez, ezanlar işitilmez, Ramazan günleri hissedilmez, çocuklar Müslümanlığın çocukluk rüyasını nasıl görürler? Isşte bu rüya, çocukluk dediğimiz bu Müslüman rüyasıdır ki, bizi, henüz bir millet hâlinde tutuyor." (Aktaran: Mardin, 2014, s. 83-84). Türk öğrencilerin cami, minare, şadırvan, başörtülü kadın gibi dinsel sembol olabilecek görüntüleri tercih etmesini inancın gereği olarak düşünmek mümkündür. "Bu resmi seçtim çünkü Müslümanım.", "Bu resim varken diğerini seçmem beklenemez, çünkü cami var." ya da "Kadın başörtülü ve Müslüman bir kadın olduğu için, bana İslam'ı hatırlatıyor." gibi ifadeler tercihlerde dini durumların baskın rol oynadığının açık bir göstergesidir.

Dil, çoğu zaman kültür aktarımını en iyi yapan araçlardan biri olmaktadır. İnsanlar anlayabildiği, anlatabildiği dili görmeyi, okumayı ve yazmayı tercih etmektedir. Farklı kültürde yaşayan insanlar, ana dillerinin dışında yaşadıkları kültürün ana dilini öğrenme sorumluluğunu taşımaktadır. Bu anlamda farklı kültürde yaşayan insanların bazılarının dili kavrama ve kullanması daha yeterli bazılarının ise daha yetersizdir. Ait oldukları kültür içinde yaşayan diğer grup olan Türkiye'de bulunan Türk öğrenciler ise kendi dillerini diğer pek çok kelime içinden ayırt edebilmiştir. Almanya'da yaşayan Türk öğrencilerin durumları bu soru için biraz daha farklı görünmektedir. Alman yoğunluğu olan bir çevrede yaşamak, öğrenim görmek ya da çalışmak özellikle dil anlamında bu kültürün içine daha çok dâhil olmak anlamına gelir. Çünkü dil, etkileşimi ve iletişimi artırır. Bunun tersi düşünüldügüünde aile içinde ve Türklerin yoğun olduğu yerlerde sürekli bulunmak kendini çevreye karşı izole etmek anlamına gelmektedir. Bu durum daha çok Türkiye'den eşle- 
riyle birlikte Almanya'ya göç eden kadınların sergilediği bir durumdur. Çocuklar, okul çevresinin ve küçük yaşta olmanın etkisiyle yeni bir dili daha kolay kabullenebilmektedir. Bu nedenle Batı kültürünü yakından bilmektedir. Batı sanat eserini tercih eden Almanya'da yaşayan bazı Tük öğrenciler için bu resim renkli ve karmaşık yapısından dolayı Amerika'daki renkli yaşama benzemektedir. Ayrıca kullanılan dili yakın ve çılgın gelmektedir. Kullanılan dilin yanında Türkiye ile özdeşleşmiş taraftar atkıları, sanatçı afişleri onları heyecanlandırmıştır. Almanya'da göremeyecekleri ayrıntıları burada görmenin kendilerini mutlu ettiğini ifade etmişlerdir. Kullanılan bazı argo kelimeler onları güldürmüş ve "Allah'a şükür Türk'üz." demişlerdir. Bu yaklaşımla değerlendirildiğinde dilin sıcaklığının, tercih ve beğenilerde etkin rol oynadığını anlamak mümkün olmaktadır.

Yapılan son araştırmalarda öğrencilerin görsel kültür çalışmalarının yardımıyla konular üzerinde eleştirel bir bakış açısı yansıttıkları görülmektedir ve ayrıca onların önceki deneyim ve bilgileri eleştirel düşüncelerini desteklemektedir (Türkcan ve Yaşar, 2011, s.1568). Almanya'da yaşayan Türk öğrenciler resimlerdeki ayrıntıları Alacakaranlık (Twilight) adlı film, Assassin's Creed IV adlı bilgisayar oyunu, Doktor Who adlı dizi, korsan gemileri ile yorumlamaktadır. Türkiye'de yaşayan Türk öğrenciler ise, resimlerdeki figür ve portreleri Sherlock Holmes film karakteri, kovboy filmleri ve American Harror Story dizisindeki cadı karakterlerine; Türk pop veya sinema sanatçlarından Sezen Aksu ve Türkan Şoray'a benzeterek beğenilerini belirtmiştir. Görsel kültür ürünlerini sanat eseri incelemesinde yorumlayan öğrencilerin tercihlerinin popüler olgulara göre değişim gösterebileceği anlaşılmaktadır. Renk ve şekil ilişkisi günümüzde popüler olan ürünlere de benzetilmiştir. Özellikle Almanya'da bulunan, grafiti ya da duvar resimlerine ilgi duyan öğrenciler, bazı eserleri bu görüntülere benzetmeleri nedeniyle tercih etmiştir. Eserlerin bakış açısı ve perspektif durumları da beğenide etkili olmaktadır. Öğrenciler farklı bir bakış açısının kullanıldığı eserleri daha çok tercih etmiştir. Örneğin 7.soruda eserin geri planının görünmesi öğrencilere ilginç gelmiştir. Eserdeki figürün baktığı yeri görmek onları heyecanlandırmıştır.

Öğrencilerin eserler, sanat akımları, tarih, sanatın ilke ve elemanları hakkında bilgi sahibi olmalarının eseri değerlendirme ve tercih sürecin- 
de etkisi olduğu görülmüştür. Sanat dersine yapılan bilgi aktarımıla öğrenciler ünlü sanatçıları, eserlerini ve yapıldığı dönemleri öğrenmektedir. Bununla ilgili bilgi birikimleri bazı öğrencilerin verdikleri yanıtlardan anlaşılmaktadır. Almanya'daki Türk öğrencilerin Caspar Friedrich'in eserini hemen tanımaları, Türkiye'deki Türk öğrencilerin ise 6.soruda bulunan kadın portrelerini duruşundan dolayı Mona Lisa ile bağdaştırmaları buna bir örnektir. Türk öğrenciler 5.sorudaki kadın figürünün elbisesinin üzerindeki lale motifinden eserin Osmanlı dönemini yansıttığı sonucuna varmaktadır. Bu durum öğrencinin belli bir Osmanlı tarihi bilgisine sahip olduğunu göstermektedir. Aynı eserde meyve tabağının klasik ancak kübist görünümü için Almanya'da bulunan Türk öğrenci Roma zamanlarını hatırlattığını; Türkiye'de bulunan Türk öğrenci de Antik Yunan'dan kalma bir eser olduğunu düşündügünü ifade etmektedir. Öğrencilerin tercih nedenlerini belirttikleri yazılarında tarih alanındaki bilgilerini yansıtan ifadeler görülmektedir. Öğrencilere göre geometrik düzende canlı renklerle yapılan eserler daha güzeldir. Hatta bu güzellik onların hayal güçlerini zorlayan gerçeküstü resimlerde daha da belirgin olmaktadır. Soyut sanatın daha güzel olduğunu ifade eden Almanya'da yaşayan Türk öğrenciye göre soyut resme her bakan kişi farklı şeyler görmektedir ve her resmin ayrı bir hikâyesi bulunmaktadır. Eserin soyut niteliğinden dolayı farklı anlamlar ifade etmesi öğrenciler için bu eseri daha güzel kılmaktadır.

Kırışoğlu (2009, s. 56), sanat yapıtı incelemenin eleştirel alanla, sanat tarihinin kültürel alanla, değerlerle düşünme ve özdeşleyimin estetik alanla ilgili bilgilerin kazanıldığı alanlar olduğunu ifade etmektedir. Sanatı kültür, tarih, toplum, felsefe ve estetik bağlam içinde ele alan bu alanlar öğrenciye sanat üzerinde düşünme, yaptığını sorgulama, kendisine sanatsal anlatımında düşünsel temel oluşturma olanağı verir. Bunun için de kuramsal bilgi en önemli kaynak niteliğindedir. Almanya'da yaşayan Türk öğrenciler de Batı sanatı ağırlıklı aldıkları sanat eğitiminde modern ve güncel sanat hakkında daha fazla bilgiye sahip olabilmektedir. Sergiler, galeri ve müzelerin her birinin sanat eğitimi alanı olduğu düşünüldüğünde Avrupa'da sanat derslerinde bu deneyimleri yaşamak için öğrencilerin farklı ülkelerdeki müzeleri görebilmek gibi imkânları daha fazladır. Ankette öğrenci cevaplarından da anlaşılacağı gibi bazı öğrenciler eserler hakkında fikirlerini sunarken kolaj, açık renkler, emp- 
resyonizm, perspektif, denge ve form gibi sanatsal terimleri kullanmaya dikkat etmiştir. Bu açıdan bakıldığında Almanya'da yaşayan Türk öğrenciler, eserin teknik ve sanat eseri açısından bilişsel olarak estetik değerini belirtme yoluyla da o eserin güzel olup olmadığına karar vermiştir.

Alanla ilgili yapılmış araştırmalardan elde edilmiş sonuçlar bu araştırmanın sonucu ile karşılaştırılarak değerlendirildiğinde benzerlikler olduğu anlaşılmaktadır. Ünlü'nün $(2012$, s.87) çalışması, öğrencilerin kültür konusunda genel olarak bilgilerinin olduğunu, ancak kültür kavramını tarihi eserler, kahramanlık sembolleri, geleneksel yemekler, dügünler, folklorik motifler, geleneksel giysiler gibi kavramları kullanarak geçmişle bağdaştırdıklarını ortaya koyması yönüyle bu araştırma ile benzerlik göstermektedir. Araştırmada algı değişimini etkileyen şartlardan birinin de çok kültürlü bir ortam ve sosyal çevre olduğu sonucuna varılmaktadır. Farklı etnik kökenden gelen öğrenciler multikültürel okullarda sadece ana dillerini kullanmakta zorluk çekmezler ayn zamanda ikinci dil olarak sosyal çevrelerinin dillerini öğrenmede de zorluk çekerler. Sonuç olarak bu problemler multikültürel toplumlarda görülen problemlerdir (Corson 1993; Cummins 1996; Wong-Fillmore, 1991; Aktaran: Erişti, 2011, s.53). Dil konusunda verilen bu bilgi ile araştırmada elde edilen bulguların aynı doğrultuda olduğu görülmektedir. Dinsel duygu ve eğilimlerin, insan irade ve düşüncesinin ürünü olmayıp içgüdüsel bir eğilim olduğunu ifade eden Şeriati'ye (2008, s.44-45) göre dini duygu ve eğilim, dinlerin getirdiği bir şey olmayıp içgüdüseldir. Dinsel eğilim, insanın fıtratı, yazgısı ve yapı taşında bulunan bir şeydir. Araştırmaya katılan öğrencilerin kendi dinlerine olan eğilimlerini belirten cevapları ile bahsedilen bu yargılar arasında benzerlik görülmektedir.

Geçmiş deneyimin öğrencilerin tercihlerinde belirgin bir etkisi olduğu görülmektedir. Öğrenciler geçmiş yaşamlarından ya da içinde bulundukları zamanda yaşadıkları deneyimlerini resimlerdeki figür, obje ya da olay yoluyla hatırlamışlar ve tercihlerini bu yönde kullanmışlardır. Dewey'in deneyimi kişisel bir varlık olarak kabul etmesinin yanı sıra kültür ve geleneklerin bir parçası olarak iletişim unsuru olduğunu savunması, her deneyimin eşsiz yani ilk olduğunu ve dönüşüme uğrayabileceğini ifade etmesi (Wickman ve Östman, 2002b, Aktaran: Wickman, 2006, s.69), öğrencilerin verdikleri cevaplar ve elde edilen bulgularla aynı 
doğrultuda görülmektedir. Coleman, Hartney ve Alderton'un (2013) sosyal hiyerarşi ile değişen ve toplumdan topluma farklılık gösteren sosyal çevreye göre estetik alg1 ve beğeninin değişmesi durumunun kültürle ilişkisini farklı örnekler sunarak göstermektedir. Geçmiş deneyimi algisal bir problem olarak değerlendiren Frixione (2011), zihne bağlı olarak gelişen kültürel içerik ve bu durumdan doğan farklı sanat formlarının bireysel algılandığını belirterek bu araştırmaya yön vermektedir.

Öğrenci tercihlerini etkileyen diğer bir unsurun da görsel kültürden etkilenme olduğu görülmektedir. Görsel kültürde pedagojik çalışmalar görsel kültürü genellikle inceleme, girişim ve değerlendirme hakkında olmaktadır (Mitchell 2002, Duncum, 2002, Tavin, 2003; Aktaran: Mamur, 2012, s.278). Mamur'a (2012, s.278) göre de özellikle görsel kültür görsel sanat eğitiminin içine dâhil edilmelidir. Bununla ilgili bazı çalışmalar farklı eğitim kurumlarında görsel kültür uygulamalarını iletmektedir. Öğrenci çizimlerinde kültürel izlerin mutlaka olduğunu belirten Wilson'a (2004, s.321) göre her genç öğrencinin ürettiği görsel el yapımı eserler kültürle çevrelenmiş bir üründür. Johannes isimli Alman bir öğrencinin çizdiği bir resimden örnekler sunan Wilson (2004, s.321), öğrencinin 16.yy'da İtalyan bir sanatçıya ait olan resmi yorumlayarak yeniden çizdiğini belirtmiştir. Bu durum tarihi bir eseri günün şartlarına uyarlama olarak değerlendirilmiştir. Öğrenci çalışmalarında görsel kültürden etkilenmenin her dönemde olacağ 1 vurgulanmaktadır. İfade edilen bu yarg1 ile araştırmada vurgulanan öğrencilerin benzetimleri ve izlenimleri birbirini doğrular niteliktedir. Erişti (2011, s.51), farklı kültürlerde yaşayan öğrencilerin çizimlerini incelediği çalışmasında öğrencilerin çoğunun tarihsel mekân, tarihsel el yapımı eserler, gelenekler, geleneksel halk sporlarl, yemekler ve kıyafet çizimlerinin görüldügünü ifade etmiştir. Farklı bir kültürde yaşayan Türk öğrencilerin pek çoğu bayram ve dügün törenlerini Türk kültürünün kalıcı konuları olarak kabul etmektedir. $\mathrm{Bu}$ öğrenciler Atatürk, geleneksel yemek ve bayrak sembollerini Türk kültürü olarak açıklamışlardır. Bu anlamda Erişti'nin (2011, s.51) çalışmasındaki sonuçlar, farklı kültürde yaşayan öğrencilerin yaklaşımları bakımından yapılan bu araştırma sonuçlarıyla benzerlik göstermektedir.

$\mathrm{Bu}$ araştıramadan elde edilen sonuçlar doğrultusunda Stokrocki'nin (1989; Aktaran: Kırışoğlu ve Stokrocki, 1997, s.3.12) öğrencilerin geçmiş ve gelecekteki kültürleri yorumlayabilme sürecini kültürler arası eğitim 
olarak nitelendirmesinden de yola çıkarak öğrencilerin kendi kültürlerinin bilincini kazanarak diğer kültürleri de öğrenip yorumlayabilecek yeterliliğe ulaşması sağlanmalıdır. Sanat eğitimcileri ve diğer öğretmenler iletişimin ve teknolojinin ilerlemesiyle tüm etkilere açık olan kültürlerin dinamik yapısının hem birbirinden ayrı hem de birbiri içerisinde anlaşılmasını sağlamayı amaç edinmelidir. Kültürel ürünlerin, gelenek ve değerlerin değerinin anlaşılması, bilinçli bir beğeniyi ve tercihi oluşturmaktadır. Güzel olma ve nitelikleri ulusal kültür ile bağdaştırılarak öğrencilerde estetik anlayış geliştirilmeli ve modern uygulamalara yansıtımı sağlanmalıdır. Bu şekilde öğrenciler sanat değeri taşıyan ve taşımayan obje arasındaki farkı algılayabilecektir. Sanat eğitimi programlarında bulunan zengin tarihsel kültür varlıklarından mutlaka faydalanmak gerekmektedir. $\mathrm{Bu}$ anlamda kültürel kimliği koruma ile birlikte evrensel değerlere de açık olmak, farklı disiplinleri bir arada ele almak ve bu şekilde yaratıcılığın gelişmesini sağlamak sanat eğitimcilerinin amaçları arasında olmalıdır. 
EXTENDED ABSTRACT

\title{
Comparison of Aesthetic Appreciation Levels of 12- 17 Years of Age Turkish Children Studying in Different Cultures
}

\author{
Hatice Kübra Özalp - Melek Gökay \\ Necmettin Erbakan University
}

In this study, it is aimed to determine the aesthetic preference or appreciation of 12-17 years of age Turkish students living in different cultures depending on cultural influences.

In the study group of the research, there are a total of 310 Turkish students, 160 of whom studying in three multicultural Gymnasium schools in Germany, and 150 of whom studying in Anatolian High Schools in Turkey. The pattern of the research consists of a mixed research model in which both quantitative and qualitative research methods are used. A questionnaire was created in accordance with the purpose of the research. The questionnaire consists of 15 questions with two correct answers, single preference and requires reasoning. In each question, two paintings, one reflecting the Turkish culture and one reflecting the Western culture are presented to the participants. The paintings in the survey were ensured to be reflecting Turkish and German cultures and be similar in terms of style, subject, colour, form and the period they were created. In addition, the artistic accumulation of the students and the art education they received were taken into consideration. Therefore, the lesson plans of the Art lesson of grades 7, 8, 9, 10, 11 and 12 in Gymnasium schools in Germany and the lesson plans of the Visual Arts lesson of grades 7, 8, 9, 10, 11 and 12 in Anatolian High Schools in Turkey were examined, and common areas in the context of unit, artist, subject, art movement and artwork were chosen. The credibility of the questionnaire was provided by obtaining expert opinion. The questions of the questionnaire applied according to the expert opinion are considered to be suitable for determining the difference between cultural differences 
and the aesthetic appreciation which is the aim of the research. During the data collection process of the research, the students chose a painting that they appreciated for each question in the questionnaire and wrote expressions indicating why they preferred it. The results of this study were obtained by quantitative and qualitative data analysis. The quantitative data obtained from the artwork preference section in the research questionnaire were analysed by (two way) Chi-Square test in the SPSS program. The qualitative data analysis, which constitutes the second part of the analysis, were obtained from the section which the students stated the reasons for their preferences with their own sentences. The themes obtained by content analysis to support the results of the quantitative analysis have been listed as the reasons of aesthetic appreciation in the research.

According to the results of the research, it is understood that the social structures, personal tendencies and past experiences of the students living in different cultures, have an effect on their appreciation and preferences in general.

The tendencies and experiences of the students due to the factor of social and physical environment have been influential on their preferences and appreciation. The concept of environment for Turkish students in Germany also shows itself as a longing for the homeland. The experience of visiting Çanakkale for both Turks living in Germany and Turks living in Turkey can be considered to be effective in making this preference. Traditional motifs and cultural symbols play an active role in students' preferences. A majority of Turkish students living in Germany and Turkey made a selection by associating most of the symbols or traditional motifs with Turkish culture.

A strong attitude in the perception of Turkish students living in Germany about national symbols such as Atatürk, the Battle of Çanakkale and flag can be noticed in Turkish students living in Turkey as well. It was also observed that this attitude was weak in some expatriate students. Moral values, traditions and especially the subject of religion are among the issues that are dominant in the appreciation. The corresponding symbol of a mosque in the minds for Turkish students living in Germany is Turkey. In some cases, it is understood that this trend can be a condition. Paintings with images that can be religious symbols such as 
mosques, minarets, fountains and women with headscarves were ensured to be preferred without a condition. Most of the Turkish students living in Germany preferred the paintings in which Turkish words were used. In addition to the language used, supporter scarves identified with Turkey, and artist posters also made them excited.

When expressing their appreciation, the students participating in the research associated the characters or images in the pictures with the characters in the publications that are popular in the visual media. Considering the popular culture factor that unites or uniforms perspective against the whole world and all cultures, it is concluded that the appreciation of students participating in the research are common at some points. It is understood that the preferences of the students who interpret visual culture products can change according to popular facts. In terms of the relationship between colour and form, paintings have also been likened to today's popular products. Especially students interested in graffiti or wall paintings in Germany preferred some works because they were similar to these images. Turkish students living in Germany interpreted the details in the works mostly with computer games, foreign film characters and pirate ships. On the other hand, Turkish students living in Turkey expressed their appreciation by associating them with Turkish pop or movie stars along with the mentioned simulations. Teaching examples of traditional and contemporary art in art education given in schools have influenced students' aesthetic preferences. The painting, which was examined in the syllabus of the Art course in Germany, was largely preferred by Turkish students living in Germany. Turkish students living in Turkey, on the other hand, distinguished the tulip motif immediately.

According to the results of the study, it is understood that the appreciation or preferences of societies which feed on past and present sources, and which exist in this wide circle called culture, change according to the environment they are in. National, religious and moral values, which form the culture of each society, education, gains from past experiences, and the trends arising from them emerge in different ways in the appreciation of individuals. The appreciation occurs among the general values of a society as a result of accumulation human beings gain in 
time. This situation sometimes should be accepted as a product of national emotions, and sometimes religious feelings or a mental process.

\section{Kaynakça/References}

Adorno, T. W. (2011). Kültür endüstrisi kültür yönetimi. (N. Ülner, M. Tüzel, E. Gen, Çev.) İstanbul: İletişim Yayınları.

Aslan, T. (2010). Kültürel yeniden-üretim süreçlerine etkisinde postmodern tüketim estetiği (Sanatta Yeterlilik Tezi). Ondokuzmayıs Üniversitesi Sosyal Bilimler Enstitüsü Güzel Sanatlar Eğitimi Anabilim Dalı, İzmir.

Baudrillard, J. (2013). Tüketim toplumu söylenceleri / yapıları. (H. Deliceçaylı, F. Keskin, Çev.) İstanbul: Ayrıntı Yayınları.

Berger, J. (2009). Görme biçimleri. (Y. Salman, Çev.) İstanbul: Metis Yayınlar1.

Berleant, A. (2010). Sensibility and sense, the aesthetic transformation of the human world. Exeter: Imprint Academy, USA: Imprint Academic Philosophy Documentation Center.

Blocker, G. H. (1993). Aesthetic value in cross-cultural multicultural art study. Arts Education Policy Review, 95(2), 26-29.

Boersema, D. (2013). Philosophy of art aesthetic theory and practice. United States of America: Westview Press, A Member of the Perseus Books Group.

Bösel, M. (2012). Religiöse und Kulturrelle probleme von muslimen in Deutschland: Möglichkeiten und irrwege einer uneingeschränkten integration. Hamburg: Diplomica Verlag GmbH.

Can, A. (2014). SPSS ile bilimsel araştırma sürecinde nicel veri analizi. Ankara: Pegem Akademi.

Canclini, N.G. (1999). Kültür ve iktidar araştırmalarının durumu. Ankara:Vadi Yayınları.

Coleman, E. Burns; Hartney, C. ve Alderton, Z. (2013). Defining “Social Aesthetics". Aesthetics, 23 (1), 1-11.

Çepni, S. (2007). Araştırma ve proje çalışmalarına giriş. Trabzon: Celepler Matbaacilik.

Dubuffet, J.(2010). Boğucu kültür. Ankara: Dost Kitabevi Yayınları. 
Duncum, P. (2004). Visual culture isn't just visual: Multiliteracy, multimodality and meaning. Studies in Art Education A Journal of Issues and Research, 45(3),252-264.

Duncum, P. (2005). Popular visual culture and ten kinds of integration. Marry Stokrocki (Ed.), Interdisciplinary Art Education, Building Bridges to Connect Disciplines and Cultures (s.107-120). Reston: The National Art Education Association.

Eagleton, T. (2011). Kültür yorumları. (Ö. Çelik, Çev.) İstanbul: Ayrıntı Yayınları.

Eckhoff, A. (2006). Influences on children's aesthetic responses: The role of prior knowledge, contexts, and social experiences during interactions with the visual arts. (Ph.D Thesis). Kansas State University, USA.

Erinç, S. M. (2004). Kültür sanat sanat kültür. Ankara: Ütopya Yayınevi.

Erişti, S. D. (2011). The perceptions of Turkish students living in different cultural environments abouts Turkish culture in their pictorial representation. Australian Art Education, 34(2), 26-58.

Frixione, M. (2011). Art, the brain and family resemblances: Some considerations on neuroaesthetics. Philosophical Psychology, 24(5), 699-715.

Gans, H. J. (2014). Popüler kültür ve yüksek kültür. İstanbul: Yap1 Kredi Yayınları.

Gökay, M. (1998), Birleştirilmiş sanat eğitimi yöntemine göre ilköğretim ii. basamağında sanat eleştirisinin uygulanması ve sonuçları (Doktora Tezi). Selçuk Üniversitesi Sosyal Bilimler Enstitüsü, Konya.

Gökay, M. (2004). Modanın görsel kültür ve sanat eğitimindeki yeri. Eğitim ve Bilim, 29 (133), 39-46.

Guyer, P. (2005). Values of beauty historical essays in aesthetic. New York: Cambridge Universit Press.

Güneş, N. H. (2004). Modernizmden postmodernizme Türkiye'de kültürel yabancilaşma sorunu (Yüksek Lisans Tezi). Mersin Üniversitesi Sosyal Bilimler Enstitüsü, Mersin.

Holt, D.K. (2001), The search for aesthetic meaning in the visual arts. USA: Bergin \& Garvey, Westport.

Kırışoğlu, O. Tekin (2009). Sanat kültür yaratıcllik, görsel sanatlar ve kültür e ğitimi-öğretimi. Ankara: Pegem Akademi. 
Kırışoğlu, O. Tekin; Stokrocki, M. (1997). Ortaöğretim sanat öğretimi. YÖK/Dünya Bankası, Milli Eğitimi Geliştirme Projesi, Hizmet Öncesi Öğretmen Ĕ̆itimi. Ankara.

Kieran, M. (2011). The fragility of aesthetic knowledge: Aesthetic psychology and appreciative virtues. E. Schellekens, P. Goldie (Ed.), The Aesthetic Mind, Philosophy and Psychology (s.32-53). New York: Oxford University Press.

Loudermilk, M. L. (2002). The use of aesthetics in a comprehensive art curriculum (Degree of Master of Art). In Art Education Graduate College Of Marshall University, Huntington, West Virginia.

Marcuse, H. (1997). Estetik boyut. (A. Yardımlı, Çev.) İstanbul: İdea Yayım.

Mamur, N. (2012). The effect of modern visual culture on children's drawings. Procedia Social and Behavioral Sciences, 47, 277-283. doi: 10.1016/j.sbspro.2012.06.651

Mardin, Ş. (2014). Din ve İdeoloji. İstanbul: İletişim Yayınları.

Prinz, J. (2011). Emotion and Aesthetic Value. E. Schellekens, P. Goldie (Ed.), The Aesthetic Mind, Philosophy and Psychology (s.71-88). New York: Oxford University Press.

Schenkman, Bo N. \& Jönsson, F. U. (2000). Aesthetics and preferences of web pages. Behaviour \& Information Technology, 19 (5), 367-377.

Schiller, F. V. (1999). Estetik üzerine. (M. Özgü, Çev.) İstanbul: Kaknüs Yayınları.

Smith, R. A. (2008). Educational aesthetics and policy. Arts Education Policy Review, University of Illinois, Urbana-Champaign, 109 (6). doi: 10.3200/AEPR.109.6.3-12

Şeriati, A. (2008). Sanat. Ankara: Fecr Yayınları.

Tunalı, İ. (2011). Estetik beğeni, çă̆daş sanat felsefesi üstüne. İstanbul: Remzi Kitabevi.

Türkcan, B. ve Yaşar, Ş. (2011). The role of visual culture studies on primary school students'interpretation of visual world. Educational Sciences; Theory EPractice, 11(3), 1564-1570.

Ünlü, İ. (2012). İlköğretim 8. sinıf öğrencilerinin kültür algılarının incelenmesi. Ahi Evran Üniversitesi Kırşehir Eğitim Fakültesi Dergisi (KEFAD) , 13(1), 77-92. 
Wagner, E. (2013). Monitoring art education. E. Liebau, E. Wagner, M. Wyman (Ed.), International Yearbook for Research in Arts Education Volume 1.(s. 101-112). Münster/New York/ München/Berlin: Waxmann.

Wickman, P. O. (2006). Aesthetic experience in science education, learning and meaning-making as situated talk and action. New Jersey, London: Lawrence Erlbaum Associates, Publishers Mahwah.

Wilson, B. (2004). Child art after modernism: visual culture and new narratives. E. Eisner, M. Day (Ed.), Handbook of Research and Policy in Art Education-1, New Jersey: National Art Education Association.

Yıldırım, A. ve Şimşek H. (2005). Sosyal bilimlerde nitel araştırma yöntemleri. Ankara: Seçkin Yayıncılık.

\section{Kaynakça Bilgisi / Citation Information}

Özalp, H. K. ve Gökay, M. (2018). Farklı kültürler içerisinde eğitim gören 12-17 yaş grubu türk çocuklarının estetik beğeni düzeylerinin karşılaştırılması. OPUS-Uluslararası Toplum Araştırmaları Dergisi, 9(16), 1307-1368. DOI: 10.26466/opus.470120 